\title{
TRANSPORT INFRASTRUCTURE PERFORMANCE AND MANAGEMENT IN THE SOUTH ISLAND OF NEW ZEALAND, DURING THE FIRST 100 DAYS FOLLOWING THE $2016 M_{W} 7.8$ "KAIKŌURA" EARTHQUAKE
}

\author{
Alistair J. Davies ${ }^{1}$, Vinod Sadashiva ${ }^{2}$, Mohammad Aghababaei ${ }^{3}$, \\ Danielle Barnhill ${ }^{4}$, Seosamh B. Costello ${ }^{3}$, Briony Fanslow ${ }^{4}$, \\ Daniel Headifen ${ }^{5}$, Matthew Hughes ${ }^{4}$, Rudolph Kotze ${ }^{5}$, \\ Janelle Mackie $^{6}$, Prakash Ranjitkar ${ }^{3}$, James Thompson ${ }^{6}$, \\ Daniel R. Troitino ${ }^{5}$, Thomas Wilson ${ }^{4}$, Stuart Woods ${ }^{7}$ \\ and Liam M. Wotherspoon ${ }^{3}$
}

(Submitted March 2017; Reviewed May 2017; Accepted May 2017)

\begin{abstract}
At 00:02 on 14th November 2016, a $\mathrm{M}_{\mathrm{w}} 7.8$ earthquake occurred in and offshore of the northeast of the South Island of New Zealand. Fault rupture, ground shaking, liquefaction, and co-seismic landslides caused severe damage to distributed infrastructure, and particularly transportation networks; large segments of the country's main highway, State Highway 1 (SH1), and the Main North Line (MNL) railway line, were damaged between Picton and Christchurch. The damage caused direct local impacts, including isolation of communities, and wider regional impacts, including disruption of supply chains. Adaptive measures have ensured immediate continued regional transport of goods and people. Air and sea transport increased quickly, both for emergency response and to ensure routine transport of goods. Road diversions have also allowed critical connections to remain operable. This effective response to regional transport challenges allowed Civil Defence Emergency Management to quickly prioritise access to isolated settlements, all of which had road access 23 days after the earthquake. However, 100 days after the earthquake, critical segments of SH1 and the MNL remain closed and their ongoing repairs are a serious national strategic, as well as local, concern.
\end{abstract}

This paper presents the impacts on South Island transport infrastructure, and subsequent management through the emergency response and early recovery phases, during the first 100 days following the initial earthquake, and highlights lessons for transportation system resilience.

\section{INTRODUCTION}

New Zealand is located on a tectonic plate boundary between the Australian and Pacific plates. The country exists because of this complex plate boundary; a subduction zone, along the east coast of the North Island, terminates northeast of the South Island, where it transitions into mostly strike-slip faults in the Marlborough and Alpine Fault regions (Figure 1).

At 00:02 on 14th November 2016, a $\mathrm{M}_{\mathrm{w}} 7.8$ earthquake occurred in the Marlborough area, resulting in two fatalities and 57 injured persons [1]. At least 21 faults ruptured on and offshore of the north-east of the South Island of New Zealand (Figure 2) [2]. The ruptures began on a fault near Culverden, approximately $15 \mathrm{~km}$ deep, and continued north-eastwards for more than $170 \mathrm{~km}$, at a rupture speed of around $1.8 \mathrm{~km} / \mathrm{s}$ $(6,450 \mathrm{~km} / \mathrm{hr})$, with Peak Ground Accelerations of around 1.3 g $[1,3]$. Initial estimates suggest between 80,000 and 100,000 landslides were triggered by the earthquake, within an area of $10,000 \mathrm{~km}^{2}$, with most of the co-seismic landslides located within an area of $3,600 \mathrm{~km}^{2}$ (Figure 2) [1]. Five landslides were more than $1,000,000 \mathrm{~m}^{3}$ in size, and 50 large landslide dams were identified $[1,4]$.

The earthquake caused widespread damage across the northeast of the South Island, including to Kaikōura, a popular tourist destination, and Wellington, the country's capital [5]. Fault rupture, ground shaking, liquefaction, and co-seismic landslides also damaged distributed infrastructure across a wide region. In particular, transportation networks were severely affected, including a number of state highways in central and northern areas of the South Island, including State Highway 1 (SH1) in the Kaikōura District, and the Main North Line (MNL) railway line between Picton and Christchurch (Figure 1). See Stevenson et al. [6] for a summary of the economic and social impacts.

SH1 is New Zealand's main highway, and runs the length of the country, supplemented by a ferry crossing between the North and South islands, run by Interislander and Bluebridge ferries (Figure 1). Prior to the earthquake, SH1 provided the main link between Picton and Christchurch $(341,500$ residents [7]), and beyond to the remainder of the South Island (Figure

1 Corresponding Author, University of Canterbury, Christchurch, alistair.davies@pg.canterbury.ac.nz

2 GNS Science, Lower Hutt, New Zealand

University of Auckland, Auckland, New Zealand

University of Canterbury, Christchurch

KiwiRail, Wellington, New Zealand

${ }^{6}$ Canterbury Civil Defence Emergency Management, Christchurch, New Zealand

${ }^{7}$ New Zealand Transport Agency, Christchurch, New Zealand 
3). SH1 was by far the shortest road route between Picton and Christchurch at around $4 \frac{1 / 2}{2}$ hours, with the closest state highway alternative route taking around $6 \frac{1}{2}$ hours.
Accordingly, SH1 carried substantial volumes of traffic and was a route for transport of goods, as well as being a popular tourist drive (Figure 3)

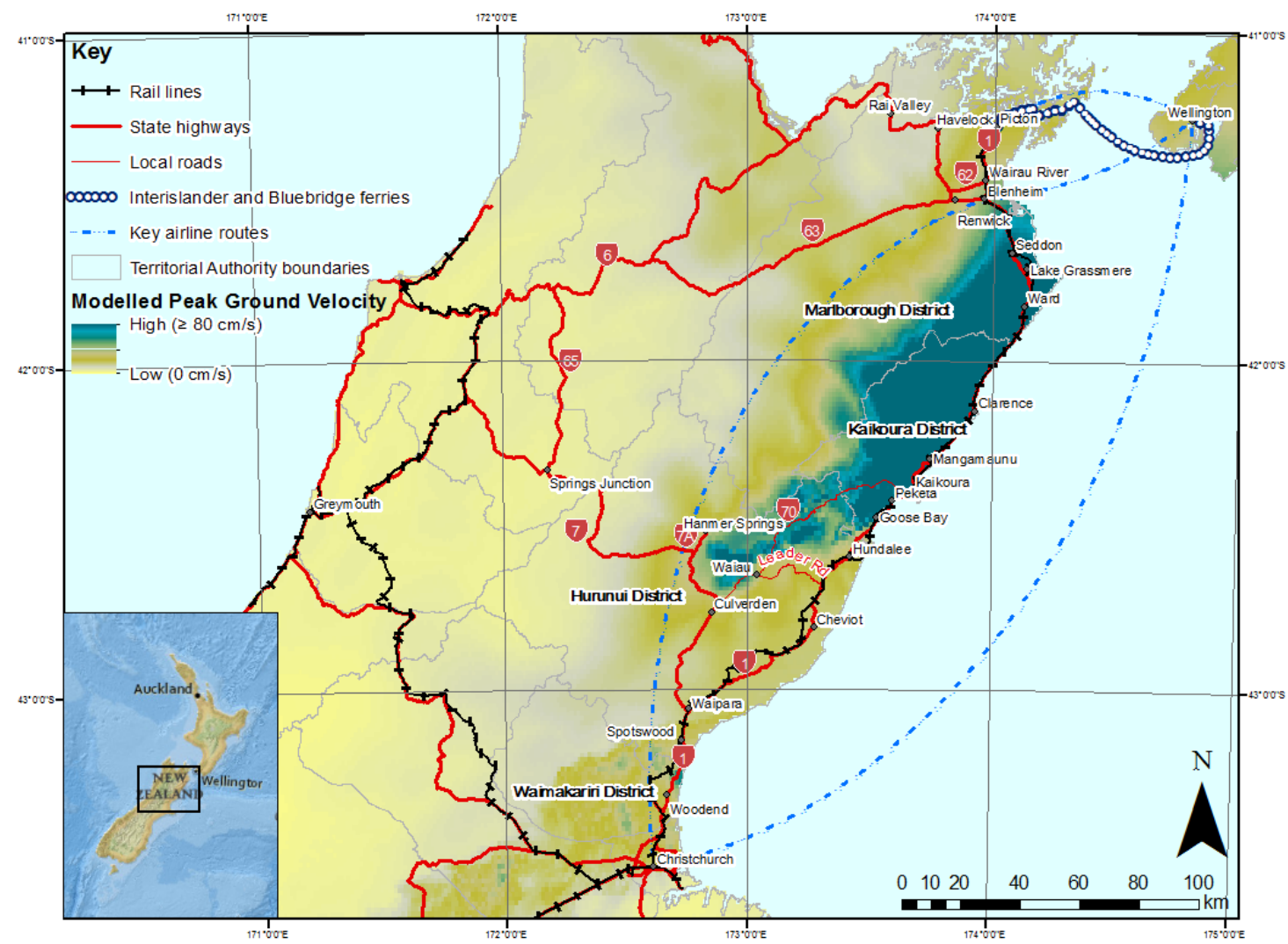

Figure 1: Modelled Peak Ground Velocity on land of the 14th November $2016 M_{w} 7.8$ Kaikōura earthquake (source: Bradley et al. [8]), with key transport networks overlaid, and New Zealand's tectonic setting (inset).

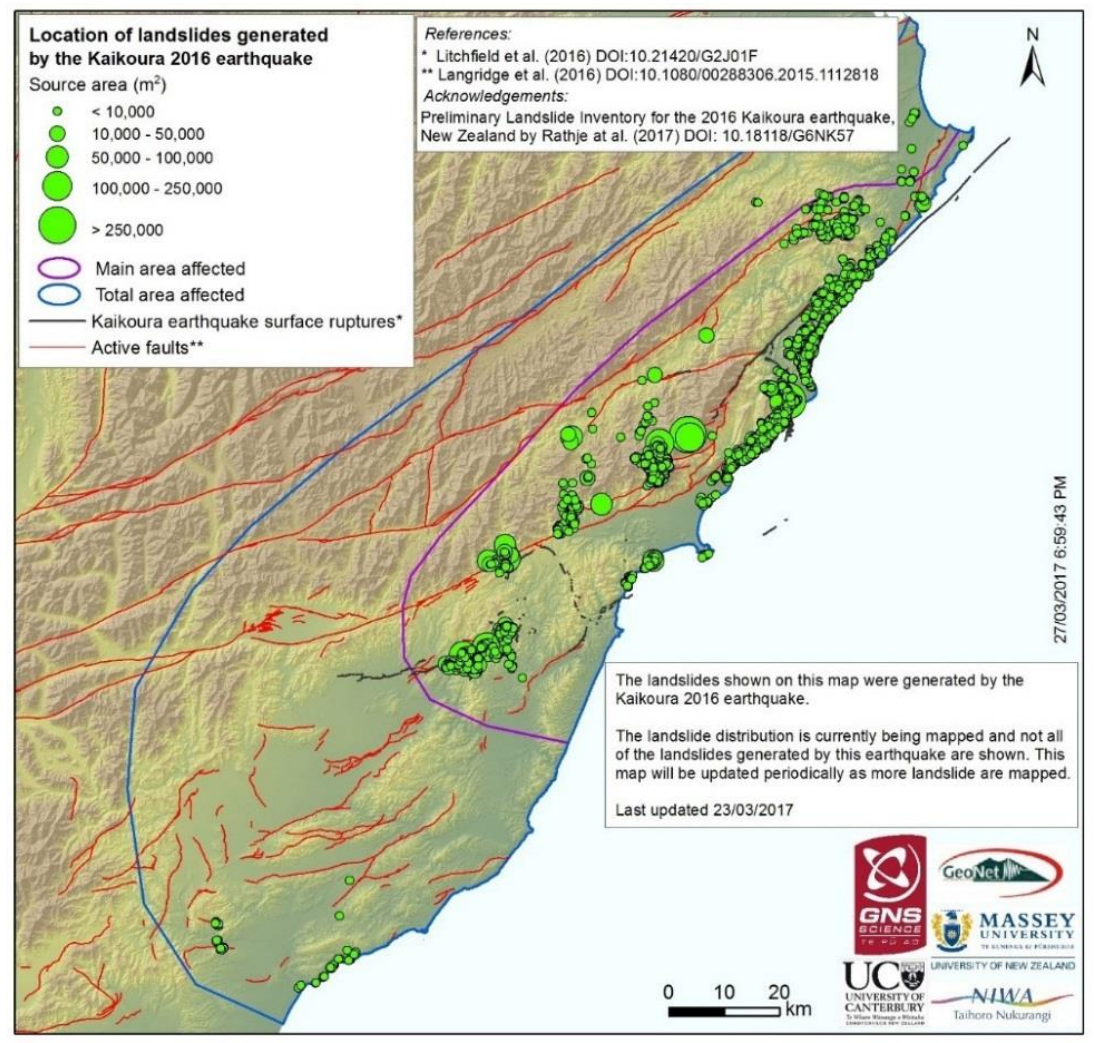

Figure 2: Preliminary Landslide Inventory for the 2016 Kaikōura earthquake, New Zealand by QuakeCoRE, GEER, and EERI [5]. 


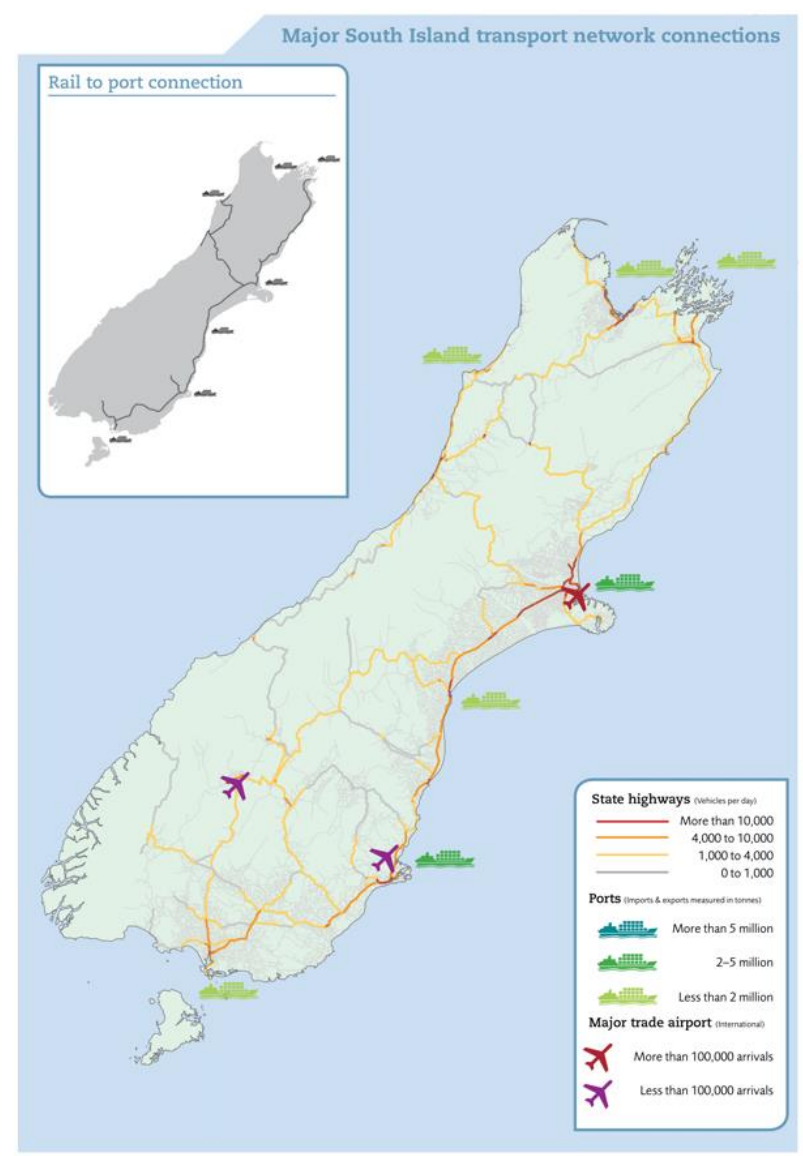

Figure 3: Major South Island transport usage by Ministry of Transport [9] (note: there is no longer a Nelson port to rail connection).

The $350 \mathrm{~km}$-long MNL runs alongside SH1 and is a critical network, moving about 1 million tonnes of freight between Picton and Christchurch annually [10] (Figure 3). The MNL is also a major tourist attraction, with the Coastal Pacific train (a KiwiRail Scenic journey service) providing a daily passenger service between Picton and Christchurch between the months of October and April.

The disruption of these transport networks caused a number of direct localised impacts, such as acute isolation of affected communities, including Kaikōura township and a number of rural farming communities, through to wider regional impacts such as disruption of supply chains [11].

This paper presents the impact of the 14th November 2016 $\mathrm{M}_{\mathrm{w}} 7.8$ earthquake on South Island transport infrastructure, and subsequent management through the emergency response and early-recovery phases, up until the 21st February 2017, 100 days after the initial event. Direct impacts on the transport network, a timeline of events, level-of-service maps, as well as secondary impacts are presented. Lessons learned from the event are also highlighted.

\section{NATURAL HAZARD RESILIENCE PLANNING RESPONSIBILITIES AND INITIATIVES FOR TRANSPORTATION NETWORKS IN NEW ZEALAND}

\section{New Zealand Infrastructure Resilience}

When considering the impacts of the Kaikōura earthquake on transport networks, it is important to consider the organisational arrangements and legislative context. New Zealand recognises that infrastructure 'is the foundation on which so much of our economy relies' [12], and so the Treasury formed a National Infrastructure Unit (NIU), which is advised by the National Infrastructure Advisory Board (which also advises the Minister of Finance and infrastructure providers). The NIU is responsible for ensuring New Zealand's infrastructure is 'resilient and coordinated and contributes to a strong economy and high living standards' [12].

The NIU has progressed from initially planning short-term priorities for infrastructure investment and regulatory reform, when established in 2009, to producing the Thirty Year New Zealand Infrastructure Plan 2015 [12]. Part of this plan aims to move New Zealand infrastructure planning away from being "asset-driven", where assets are 'designed and built without fully considering the service being delivered' [12], to ensuring infrastructure providers understand end users' needs. This priority was highlighted again in the Treasury's Progress one year on from the Thirty Year New Zealand Infrastructure Plan report, which states 'simply building things to address our problems is no longer sustainable. We need a better understanding of the levels of service we want to deliver, more mature asset management practices and use of data, and more effective decision-making that considers non-asset solutions' [13]. Therefore, New Zealand government policy increasingly views infrastructure in terms of the integrated service provided; instead of, for example, considering roads, rail lines, shipping and air travel separately, increasingly the focus is on the ability to transport goods and people around the integrated transport network, regardless of the transport mode.

Section 60 of the Civil Defence and Emergency Management Act 2002 [14] requires lifeline utilities 'to be able to function to the fullest possible extent', even though this may be at a reduced level, during and after an emergency. To this end, New Zealand has an increasingly strong "Lifelines" culture. Lifeline utilities are entities that provide essential infrastructure services to communities and have responsibilities for planning and coordinating in a way which enables the continuation of these services in an emergency, as part of Civil Defence and Emergency Management (CDEM) Groups, the Ministry for Civil Defence and Emergency Management (MCDEM), and other relevant government agencies and regulatory bodies, legislated under the National Civil Defence Emergency Management Plan Order 2015 [15]. A key feature of the Lifelines culture in New Zealand is the 16 Regional Lifelines Groups across New Zealand, with national representation and coordination undertaken by the New Zealand Lifelines Council (est. 1999). These regional entities, made up of lifeline utility representatives, undertake collaborative work with scientists, engineers and emergency managers to identify interdependencies and vulnerabilities to regional scale emergencies. This collaborative process provides a framework to enable integration of asset management, risk management and emergency management across utilities $[16,17]$.

A notable success story of the value of the Lifelines concept is the Christchurch Engineering Lifelines' Risks and Realities project [18], which identified a number of vulnerabilities and interdependencies in Christchurch in the late 1990's and over the subsequent decade implemented a suite of disaster risk reduction measures. A review of the impact of these mitigation measures following the 2010/2011 Christchurch earthquake sequence found 'the damage would have been greater and the response slower if the steps recommended in Risks and Realities and other preparatory work fostered by the Group had not been taken. For example, Orion's electricity distribution seismic strengthening programme, commenced in 1996 and progressed systematically each year, cost \$6 million and is estimated to have saved $\$ 60$ to $\$ 65$ million in direct asset replacement costs and repairs [15, 19]. 


\section{New Zealand Transport Network}

The New Zealand transport network is owned and operated by several different organisations. The New Zealand Transport Agency (NZ Transport Agency) is an independent crown entity, responsible (amongst other roles) for allocating funds from the National Land Transport Funds to land transport activities, including local roads, state highways and public transport and, together with local and regional government, for funding local roads and public transport infrastructure and services. NZ Transport Agency is responsible for the state highway road network (Figure 1). Local roading is the responsibility of territorial authorities in the form of district or city councils. KiwiRail is a state-owned enterprise and the largest rail transport operator in New Zealand, including rail operations in the South Island, and Interislander ferries (Figure 1). KiwiRail's 'core purpose' is to move people and freight, and aims to add value to New Zealand transport by helping their customers to be more competitive, assisting with the Government's Business Growth Agenda and offering worldclass tourism experiences [20]. Bluebridge operates the other main ferry service between Picton and Wellington (the South and North islands) (Figure 1). Numerous other shipping companies operate throughout New Zealand waters, and numerous private airlines operate throughout the country (Figure 1, Figure 3). Air New Zealand is the national airline, $53 \%$ owned by the New Zealand Government.

NZ Transport Agency and KiwiRail (alongside Transpower, the national electricity provider) have developed a shared resilience response framework, aligned with the Thirty Year New Zealand Infrastructure Plan 2015 [21]. Using a consistent approach allows better management of, and cooperation between, the networks. Resilience is viewed by the collaborators as being concerned with any event, natural or man-made (including, for example, climate change), which could disrupt the networks. The framework is based around three strands: 1) prevention, mitigation and preparedness; 2) emergency response; and 3) restoration and rehabilitation.

NZ Transport Agency has undertaken further resilience work specific to its network, through: business continuity planning; identifying alternative routes to state highway links; creating a system to advise customers of events, impacts and their options; and continuing with seismic retrofit, bridge scour and rockfall mitigation programmes; avalanche and weather monitoring programmes; efforts to proactively reduce ice formation on road surfaces; and to build new structures to modern standards [21]. However, NZ Transport Agency's most recent "State Highway Network Resilience National Programme Business Case" [21] identified a number of areas where improvements were needed:

- 'while alternative routes are planned for each state highway these are not consistently recorded, nor do they all have sufficient capacity to be viable alternatives without upgrade;

- 'there is an inconsistent process used in different regions for assessing natural risks making it difficult to consistently assess, compare and prioritise service gaps and potential responses;

- 'there has been no systematic framework for recording events, or assessing infrequent risks so current knowledge of risk tends to be dominated by the frequently occurring events causing a dearth of reliable systematic assessment of the scope, location or risk of infrequent events' [20, p. 3].

NZ Transport Agency's Capital Works Programme develops projects based upon a range of criteria, including a costbenefit analysis, which can make it difficult to deliver projects with "resilience" as the primary objective or justification, though it should be noted "resilience" is often a secondary objective in Capital Works Programme projects. This is because, for example, even for a relatively frequent natural hazard recurrence interval of 50 years, the annual benefit needs to be divided by 50. Calculating a Net Present Value (calculated for a 40-year period and with a relatively low $6 \%$ discount rate) from the annualised benefit stream often results in a value so small that it rarely becomes a priority, compared to other possible improvements such as road safety.

KiwiRail have developed several systems for consistent nationwide review of resilience related issues. Rating individual slopes in terms of a "Slope Risk Ranking" allows individual slopes to be compared on a consistent basis across the national rail network. Over 3,000 slopes have been ranked in this manner. Additionally, KiwiRail records all incidents across the rail network and regularly reviews these compared to asset information such as the Slope Risk Ranking. From this investment, choices for mitigation can be undertaken.

Network-specific resilience improvements have also been made for shipping and air transport, as lifeline utilities. Unfortunately, there is little publicly-available relevant information on specific initiatives for these networks.

Isolated settlements, as well as wider regions supported by supply chains, are increasingly dependent upon distributed infrastructure. Due to this dependency, by causing damage to distributed infrastructure, natural hazards can now threaten beyond their local, direct impacts. The 14th November 2016 earthquake offers important insights into these increasing risks, and, accordingly, the success of specific resilience initiatives within the transport sector.

\section{METHOD}

This paper presents the impact of the 14th November 2016 $\mathrm{M}_{\mathrm{w}} 7.8$ earthquake on South Island transport infrastructure, and subsequent management through the emergency response and recovery phases, up until 21st February 2017, 100 days after the initial earthquake. Throughout this paper, dates are referred to as "Day X", with 14th November 2016 being Day 1 and 21st February 2017 Day 100. This paper uses data immediately available after the emergency response phase. A complete overview of the physical and functional performance of all South Island transport is beyond the scope of this paper.

The earthquake and co-seismic hazards, as well as direct impacts on road, rail, bridges, shipping and air transport are briefly summarised before presenting a detailed timeline of key transport events, derived from discussions with representatives from the NZ Transport Agency Christchurch branch, Canterbury CDEM, and KiwiRail (co-authors), as well as publicly-available information from NZ Transport Agency, KiwiRail, CentrePort, SoundsAir, CDEM, Marlborough District Council, Kaikōura District Council, Hurunui District Council, Waimakariri District Council, and the media. From this timeline, maps are produced to show level-of-service changes between 14th November 2016 (Day 1) and 21st February 2017 (Day 100), for: state highway roads and alternative routes; rail lines, Interislander rail-enabled ferry services and official KiwiRail diversions; Interislander and Bluebridge vehicle and passenger ferries; and commercial flights between Kaikōura, Christchurch, Wellington, Blenheim, and Picton. Secondary impacts are then presented, before discussing the timeline of transport interdependencies during the emergency response and initial days of recovery in the South Island, followed by lessons from the event. 


\section{IMPACT ASSESSMENT}

\section{Direct Impacts}

The direct impacts of the earthquake and co-seismic hazards on road, rail, bridges, air transport and shipping are summarised below.

\section{Road}

The impact of the earthquake on roading was severe. Prior to the earthquake, the travel time between Christchurch and Picton was around 4 1/2 hours using SH1. Immediately after the earthquake, the road travel time increased to more than 8 hours. SH1, New Zealand's main highway, was closed between Waipara and Wairau River township and $\mathrm{SH} 7$ (including SH7A) was closed between Waipara and Springs Junction (Figure 12). Smaller roads (including Route 70) were also closed, making Kaikōura, Hanmer, and a number of smaller settlements in the area inaccessible by land. Freight, vehicle and passenger ferry services between the North and South islands were suspended until damage to Wellington port could be assessed and berths cleared for use (Figure 12).

Ground movements caused severe road cracking due to slope failure beneath the carriageway (Figure 5a) and vertical and horizontal displacement due to fault rupture (Figure 5b), making the roading network impassable at a number of locations immediately after the event (Stirling et al. [2] provides an overview of fault rupture locations and impacts). Road damage due to slope instability beneath the carriageway was repaired in the first few days following the earthquake in all locations apart from those inaccessible due to other damage typologies. The earthquakes also increased the risk of coseismic hazards. Co-seismic landslides (Figure 5c) and rockfalls (Figure $5 \mathrm{~d}$ ) closed the road in a number of places, and have presented one of the greatest challenges in repairing the road requiring a substantial amount of time and effort to clear. A more complete summary of landslides and their impacts is presented in Dellow et al. [4].

By the end of Day 1, SH1 had reopened from Waipara to Cheviot and $\mathrm{SH} 7$ between Waipara and Springs Junction (including daytime access along SH7A to Hanmer Springs, which was no longer isolated) (Figure 13), resulting in the travel time between Christchurch and Picton reducing to around $6 \frac{1}{2}$ hours. By Day 2, car ferry services had also resumed, albeit reduced services, making road travel between the North and South islands viable again (Figure 14).

CDEM quickly prioritised access to isolated settlements, in particular to provide essential supplies including water, food and fuel, and to evacuate the hundreds of tourists who were trapped in Kaikōura (primarily to reduce the load on local supplies). Prior to the earthquake, Kaikōura was accessible from the north and south by a coastal rail service and SH1, as well as via Route 70 from the south-west (Figure 1). Most of the smaller settlements in the area were accessible exclusively by road. Following the earthquake, settlements (including Kaikōura) were inaccessible by land (Figure 13).

Despite facilitating efficient evacuation, access via air and sea were both unreliable. For air access, poor weather conditions could (and did) result in no-fly days, and for sea access, damage to Kaikōura port, as well as its small size, meant few vessels could dock [22]. The sea bed around the port was uplifted and so needed to be re-surveyed for access for anything other than small boats [2]. This meant access was dependent on the ability to moor offshore, and thus sea conditions. Therefore, it became critical to re-establish road access.

NZ Transport Agency began to clear SH1 from the south of Kaikōura at 06:00 on Day 2, a decision NZ Transport Agency described as "fairly self-evident" because the landslides north of Kaikōura were much larger, meaning there was greater opportunity to pursue getting the roads open to the south. While work began on clearing SH1, a number of options were considered by NZ Transport Agency and CDEM, and Route 70 was decided as the most feasible road to secure quick access to Kaikōura.

Within the first few days, SH1 between Peketa and Mangamaunu was opened (Figure 15), and army convoys began travelling along Route 70 through to Kaikōura (and so also reached Peketa and Mangamaunu). These convoys carried essential supplies, at the request of the Emergency Operation Centre in Kaikoura and Canterbury CDEM. Before the convoy proceeded, a 10-step "go/no-go" assessment (Figure 4) was conducted every morning at around 06:00, which involved a visual assessment of the road and geohazards (including landslide reconnaissance) by helicopter, or by road if the weather did not permit flying, weather forecast assessment, establishing whether the travel was essential, and creation of a recovery plan. Later, specific vehicles needed to repair critical infrastructure were also permitted access along Route 70 .

\section{Go / No Go}

Weather + Fx
Road State
Geo Tech Risks
Other Road Users/Activities
Emergency Response Procedure in Place
Turn Back Criteria
Public Messaging
'Safe' Zones Identified
'High Hazard' Zones
Load, Speed, Weight Restrictions
Date:

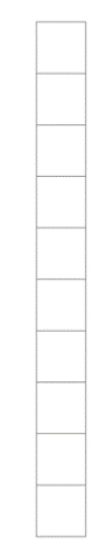

Figure 4: Canterbury CDEM “Go/No Go” criteria.

Road access was a balancing act between three factors: 1 . repair of the road; 2. (emergency) supplies for Kaikōura; and 3. access for residents (particularly for farmers to make repairs). Prioritisation of any of the factors slowed down the other two, meaning effective management and operation was critical.

By Day 4, SH1 was open between Blenheim and Ward, and there was controlled access along SH1 between Cheviot and Goose Bay, reducing the number of completely isolated settlements (Figure 16).

On Day 11, the first non-emergency vehicles travelled out from Kaikōura. 81 vehicles travelled in convoy, subdivided into vehicle classes (i.e. cars, trucks), through Route 70 under heavy supervision due to the risk the road still presented. Those wishing to travel in a convoy registered beforehand, and met in specified locations before proceeding, subject to the 
"Go/No Go" criteria. Daily convoys in and out of Kaikōura along Route 70 continued until Route 70 was switched to controlled access for residents and emergency services on Day 23, when SH1 between Ward and Clarence was also opened for controlled access, meaning all settlements had road access (Figure 21). However, the SH1 diversion remains in place 100 days after the event, as SH1 remains closed between Mangamaunu and Clarence as repair works continue (Figure 24).

On Day 38, Route 70 was fully reopened and daytime access between Goose Bay and Peketa along SH1 to Kaikōura was also permitted, adding some redundancy in accessing Kaikōura (Figure 23). This section of SH1 closed three times during December and January, twice for a few hours due to weather conditions increasing the risk of rockfall onto the

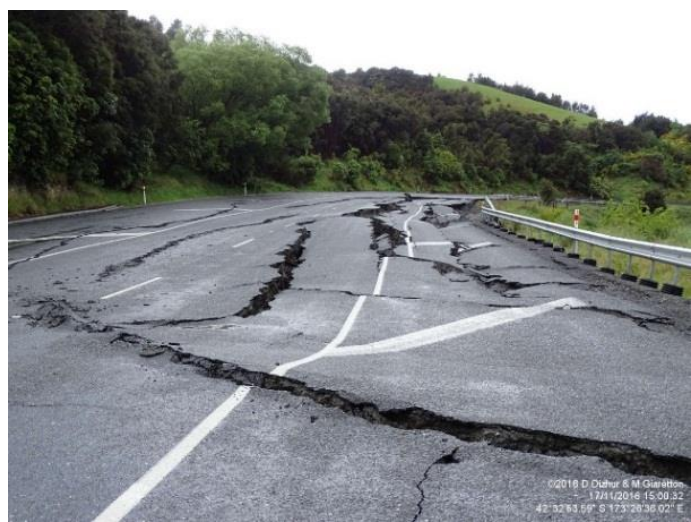

(a) Pavement cracking on SHI due to slope instability. Photo credit: Dizhur \& Giaretton highway, and then for two days due to a slip. Route 70 remained open throughout.

Rail

The earthquake and co-seismic hazards caused substantial damage to the rail network. Immediately following the earthquake, all rail and rail ferry services between Palmerston North (north of Wellington) and Christchurch were suspended by KiwiRail until a rapid survey of the affected region was completed (Figure 25). One train was trapped between damaged sections of the Main North Line (MNL) north of Kaikōura, as it stopped where it was during the earthquake (as is normal operating procedure). The train was not damaged by the earthquake.

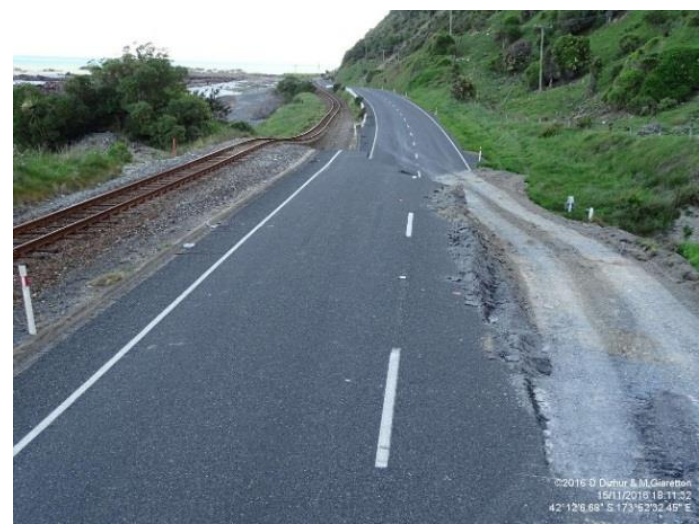

(b) Pavement rupture due to fault rupture and subsequent access ramp. Photo credit: Dizhur \& Giaretton

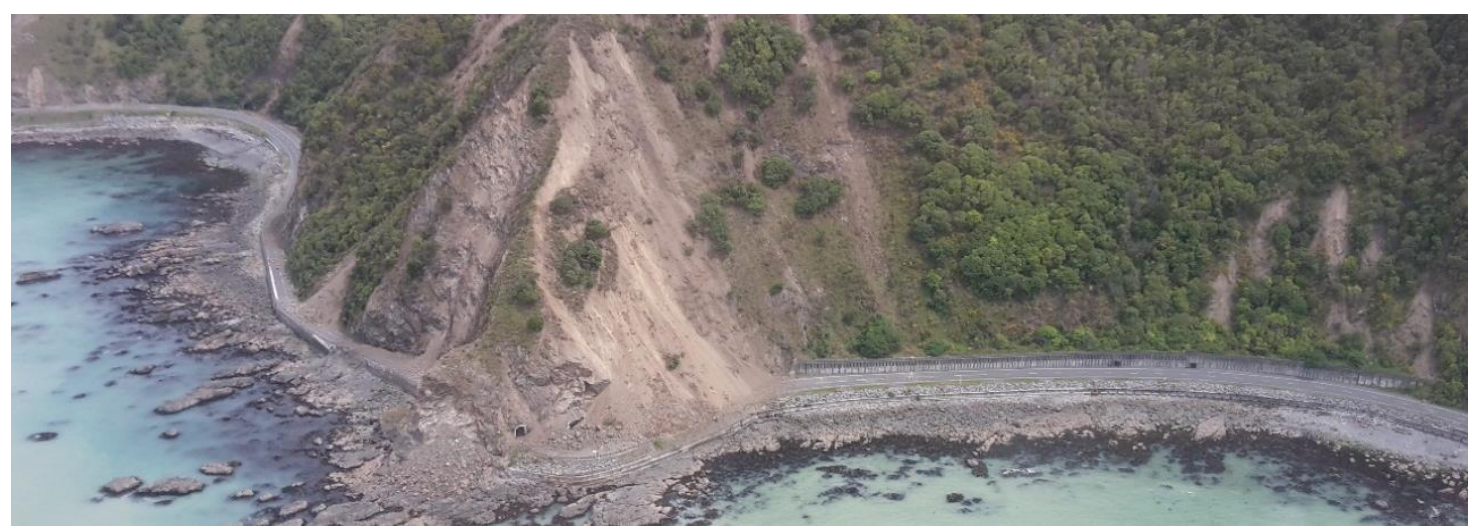

(c) Landslide on SH1, north of Kaikōura. Photo credit: Tonkin \& Taylor

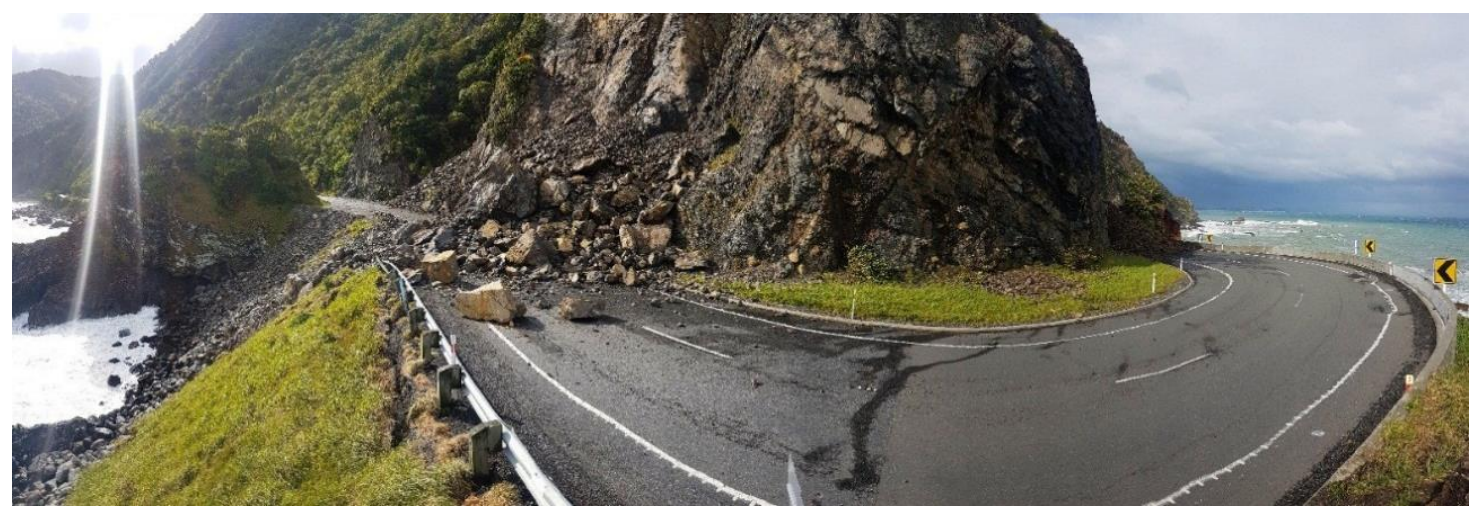

(d) Rockfall on SH1, north of Kaikōura. Photo credit: Dizhur \& Giaretton

Figure 5: Photos of road damage on SH1, following the 14th November 2016 earthquake. 


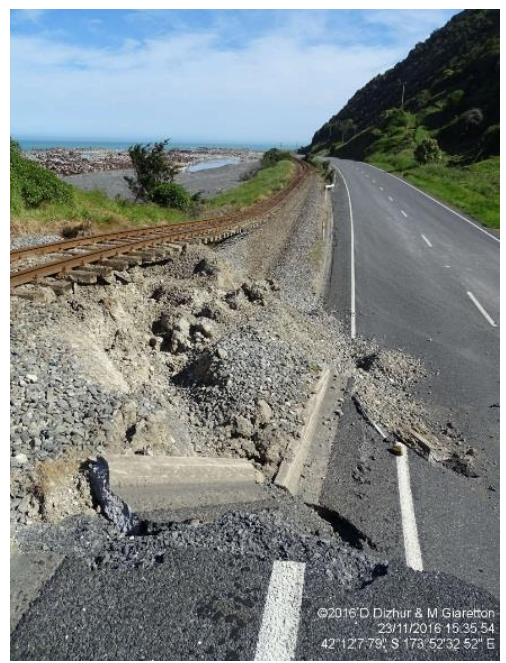

(a) Rail line suspended by fault rupture (angle 1). Photo credit: Dizhur \& Giaretton

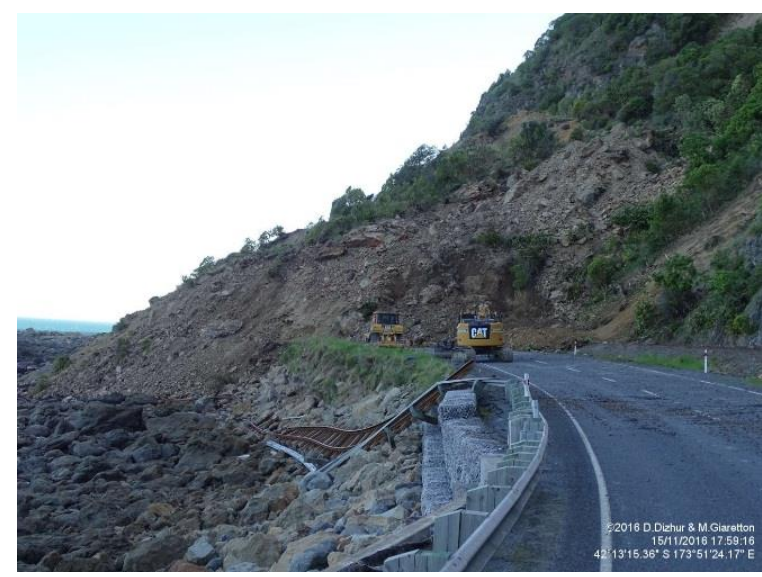

(c) Large offset of rail track due to landslide Photo credit: Dizhur \& Giaretton

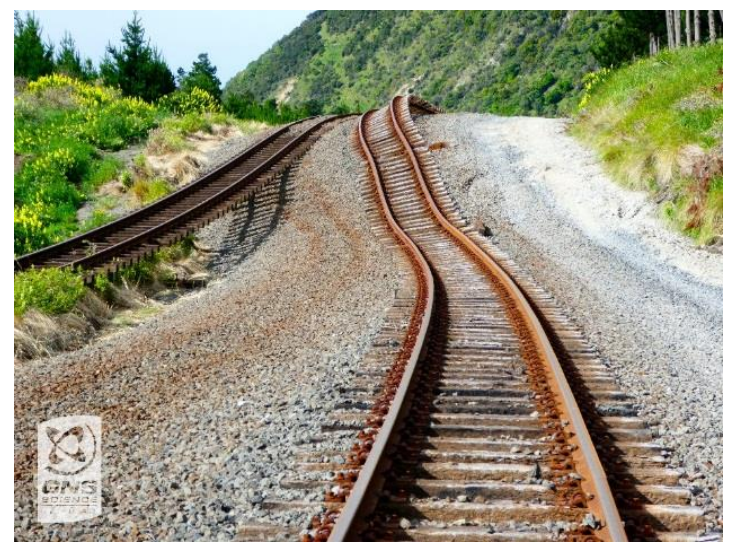

(e) Rail tracks severely distorted and misaligned due to fault rupture. Photo credit: William Ries, GNS Science

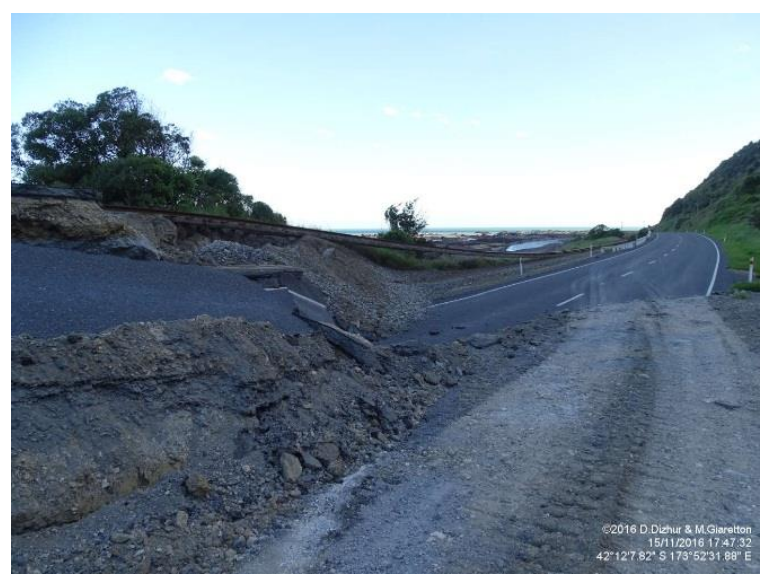

(b) Rail line suspended by fault rupture (angle 2). Photo credit: Dizhur \& Giaretton

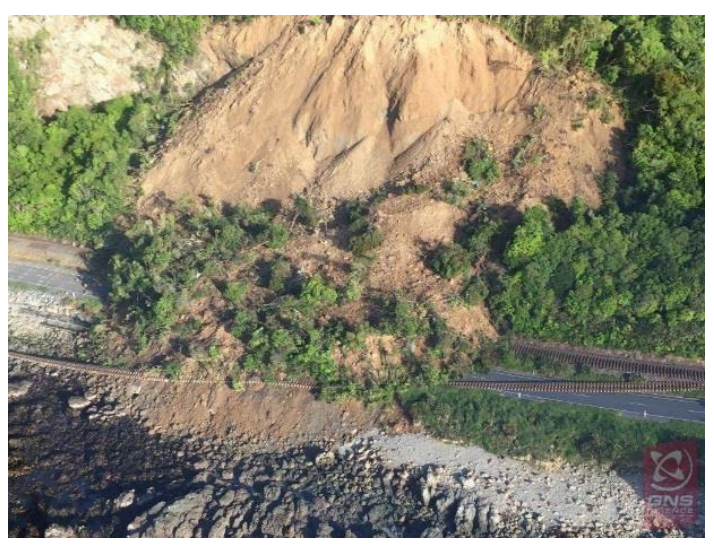

(d) Large offset of rail track due to landslide Photo credit: William Ries, GNS Science

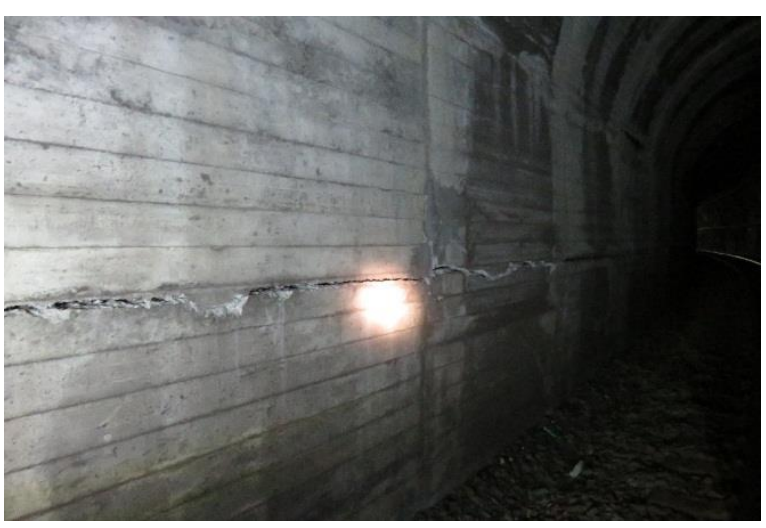

(f) Cracking of tunnel wall. Photo credit: KiwiRail.

Figure 6: Photos of rail damage, following the 14th November 2016 earthquake.

While passenger rail services in the Wellington area fully resumed within 3 days following the earthquake, the majority of the MNL remains closed over 100 days later (Figure 30).

KiwiRail started to assess and inspect the damage immediately after the earthquake, following the procedure in their
"Earthquake Response for Infrastructure" Standard, with track gangs and inspectors undertaking visual inspections on accessible areas and flyovers over the inaccessible section around Kaikōura. Engineering inspections also commenced within two days of the earthquake, with multiple teams 
assessing damage simultaneously along the MNL. In order to maintain consistency in recording damage observations made by the multiple teams, a KiwiRail-developed "Damage Classification Guideline" for rail assets was used. Continued aftershocks and the very high risk of further landslides meant inspections had to be conducted in a controlled fashion. The impact of aftershocks was assessed according to the above KiwiRail Standard, which required constant review of Peak Ground Acceleration (PGA) readings following aftershocks and subsequent inspections (when required).

Preliminary observations suggest that about 700-750 sites along the MNL were affected by this event, with tracks, bridges, tunnels, culverts, slopes, embankments and communication systems all damaged to varying degrees [23]. Figure 6 and Figure 7 show examples of damage observed and recorded from the visual inspections. Detailed damage observations on rail assets are still being collated.

Rapid assessment and repairs were made to reopen the MNL between Picton and Blenheim by Day 3, thus providing rail access to carry freight from Picton to the container transfer site at Springs Creek, north of Blenheim (to be later delivered by truck to Christchurch) (Figure 26).

The rail service between the North and South islands also relies upon a rail-enabled ferry. This did not resume sailing until Day 16, when the link span at the CentrePort ferry terminal in Wellington, used to load and discharge vehicles, was repaired (Figure 27).

Repair works on the heavily damaged MNL continued throughout the Christmas holiday period. This resulted in the reopening of a significant section of the MNL between Picton and Grassmere by Day 64, which allowed commercial goods to be carried between Dominion Saltworks at Lake Grassmere and Picton (Figure 29). These repairs also freed train wagons trapped near Lake Grassmere, allowing the carriages to be redistributed around the rail network. The train stopped partially within a tunnel near Kaikōura, has been moved to a different location along the MNL to take the heavy locomotives off a bridge to prevent damage from future aftershocks, but remains trapped. Work trains were able to be run from Christchurch north to Bridge 83 on the MNL for load testing of the structures on Day 25, but could not travel further due to formation and bridge damage.

Numerous teams continue to work collectively to identify badly damaged assets and to explore repair strategies, with achievements including: completed concept designs for strengthening and/or replacements of major damaged bridges and initial construction schedules; continued repairs to twisted tracks; detailed geotechnical assessments and testing carried out at a number of affected sites to prepare for major earthworks; and surveying of damaged tunnels to determine repair work required. Three months following the earthquake, repair and restoration works on 120 out of over 800 sites have been completed, and efforts are continuing to restore the remaining sections of MNL back to full service by the end of 2017.

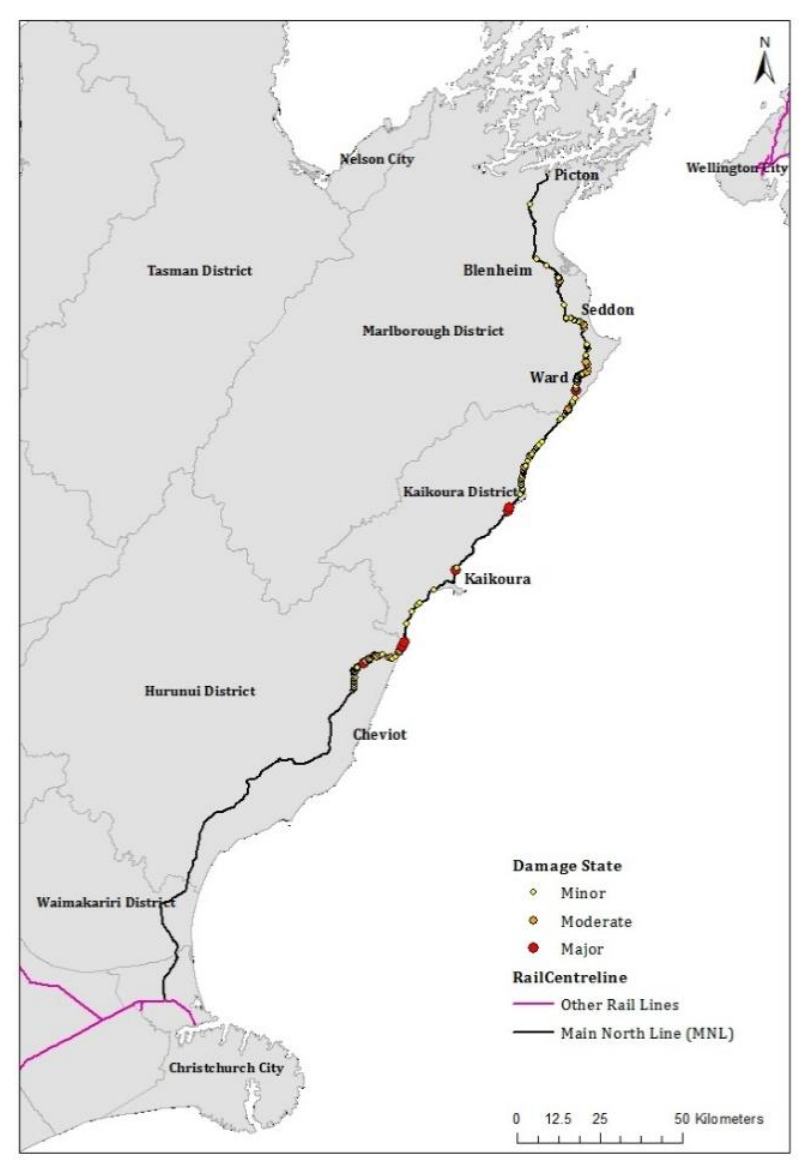

Figure 7: Track damage states assigned (following the "KiwiRail Earthquake Damage Classification Guideline") based on visual inspection of tracks: Minor (e.g. very minimal damage to rail and/or sleepers), Moderate (e.g subsidence of track $>150 \mathrm{~mm}$ and/or over a distance $>50 \mathrm{~m})$, and Major (e.g. significant vertical and/or horizontal movement).

\section{Bridges}

The vast majority of bridges performed well during the earthquake, with most being allowed to re-open after inspection in the first few days after the earthquake. Some bridges with damage to their piers were cleared for use before repairs were completed (Figure 8b, Figure 8c, Figure 8d).

Although the bridge structures withstood the earthquakes well, demonstrating considerable robustness, many bridge approaches were damaged due to settlement and horizontal movement (Figure 8a), thereby making some bridges impassable. Approach reconstruction through the placement of fill and resealing quickly made the majority of these road bridges usable again. In some locations diversions were put in place to bypass damaged road bridges (such as the Oara Bridge in Figure 8a that crosses rail lines), and along Route 70 one bridge was replaced by a temporary Bailey bridge alongside the repair to other parts of the Route to allow for access. Displacement is a greater problem for rail lines than roads, whether vertical or horizontal (Figure 8e). However, given the damage to other parts of the rail network, this damage is not immediately critical, and repair can be scheduled accordingly.

Palermo et al. [24] provide an in-depth summary of the structural and geotechnical engineering-related impacts to road bridges. 


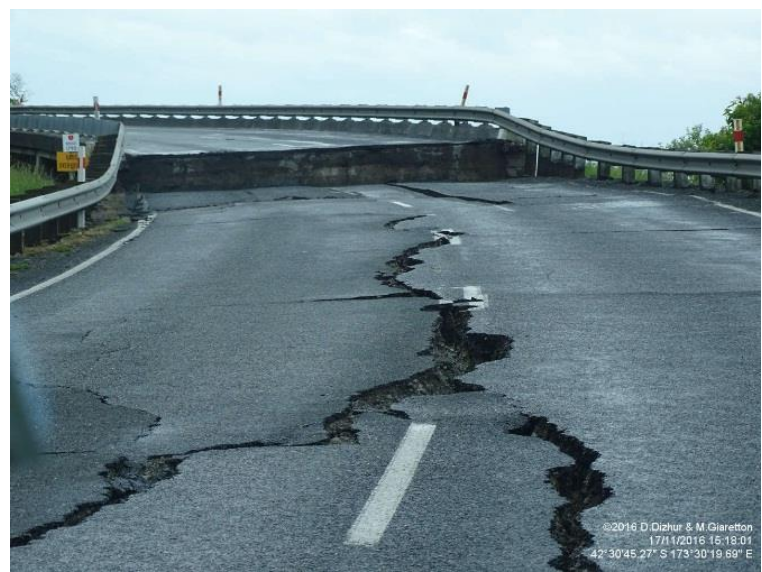

(a) Oaro bridge approach failure and pavement cracking. Photo credit: Dizhur \& Giaretton

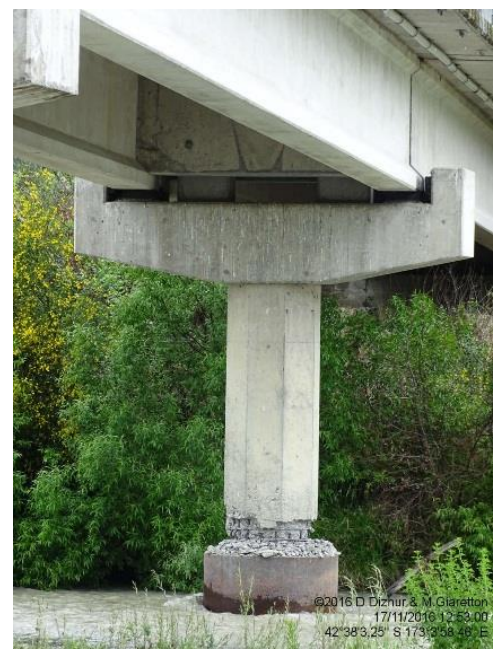

(c) Lower Mason bridge support damage. Photo credit: Dizhur \& Giaretton

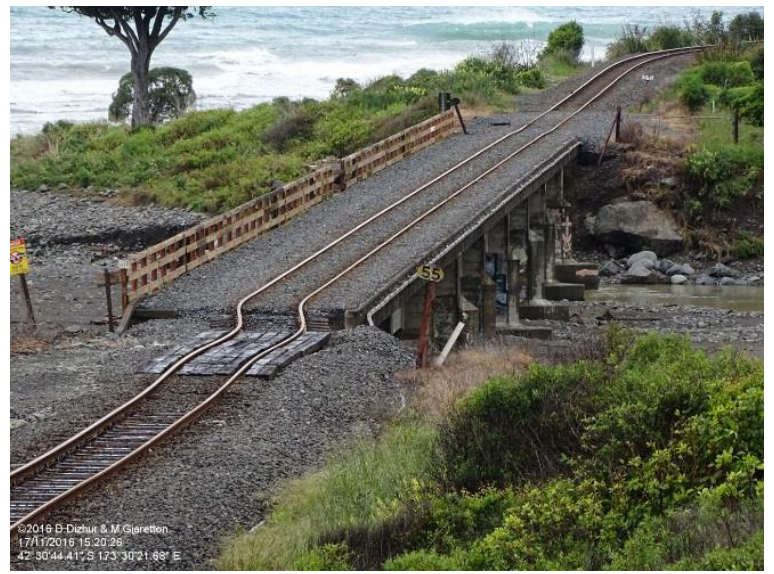

(e) Rail bridge 97 MNL approach offset and rail alignment failure. Photo credit: Dizhur \& Giaretton

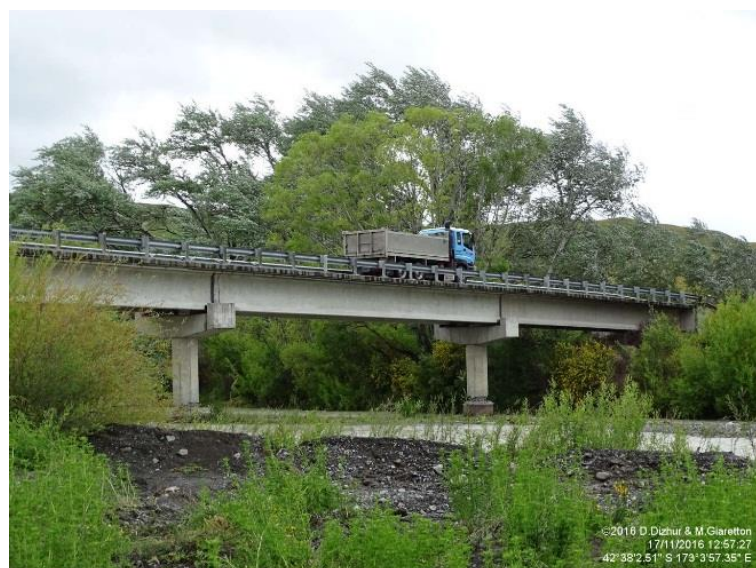

(b) Lower Mason bridge with damaged supports. Photo credit: Dizhur \& Giaretton

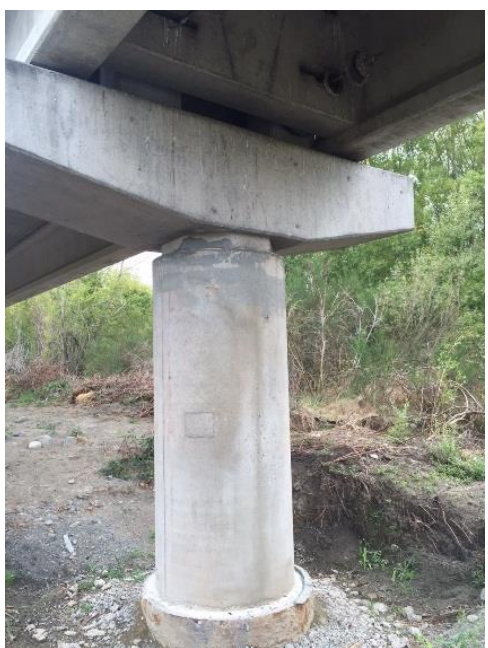

(d) Lower Mason bridge support repair. Photo credit: Liam Wotherspoon, UoA

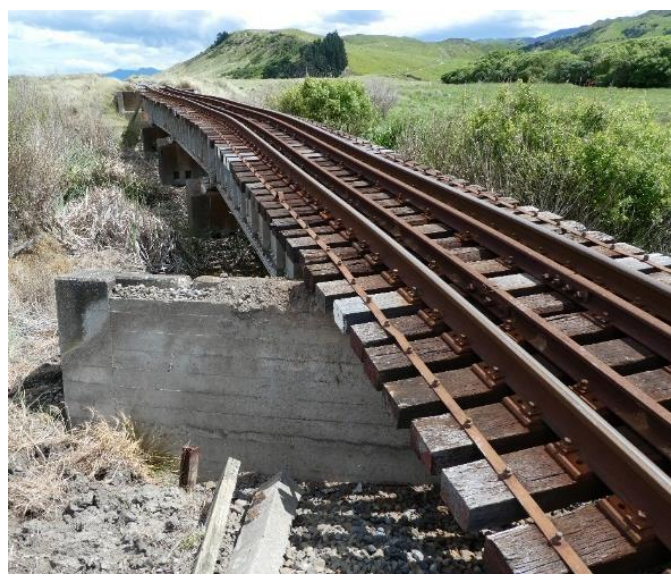

(f) Rail bridge 129 MNL span dislocated from abutment due to Kekerengu Fault rupture. Photo credit: Tim Little, $V U W$.

Figure 8: Photos of bridge damage on SH1 and rail, following the $14^{\text {th }}$ November 2016 earthquake.

\section{Shipping}

Most ports throughout New Zealand were undamaged by the earthquakes, with the major exception of CentrePort in Wellington, which suffered substantial damage due to liquefaction-induced settlement and lateral spreading, rendering the port's container cranes inoperable [25].
Two ferry services, Bluebridge and Interislander, provide the main ferry link between the North and South islands between Wellington and Picton. Ferry services between Wellington and Picton resumed by Day 2 (Figure 14), with the only major restriction being for foot passengers, who could not board the ferries due to terminal damage. By Day 4, foot passage was again possible both ways between Wellington and Picton on 
Bluebridge services (Figure 16), although full Interislander operation did not resume until Day 23 (Figure 21).

Kaikōura port was also damaged. The sea bed around the port was uplifted and needed to be re-surveyed for access for anything other than small boats [2]. In part also due to its small size, this meant sea access to Kaikōura was dependent on the ability to moor offshore, and thus sea conditions.

\section{Air Transport}

There were no major direct impacts to the air network. Wellington and Christchurch international airports, and Kaikōura and Blenheim regional airports were undamaged and virtually uninterrupted, following brief (less than one hour) closures for inspections.

\section{Secondary Impacts}

\section{Road}

The vulnerability of the state highway network to different and cascading hazards presented a substantial risk throughout the emergency operation, and continues to do so during the recovery phase, especially to working crews who must carefully execute tasks in a controlled manner due to the risks. Figure 9a shows an example of fault rupture increasing the risk of a landslide onto the road, and Figure $9 \mathrm{~b}$ shows an example where a landslide below the road has increased the risk of slumping. Canterbury CDEM noted these hazards were not apparent when viewed from road level, despite the obvious threat they presented when viewed from above as part of an aerial geotechnical assessment.

Perhaps the most substantial secondary impact to the state highway network was that the section of SH6 between SH63 and SH65 became the only section of road connecting Canterbury, the West Coast, Southland and Otago to the North Island through Picton and Wellington. Presently, there is no redundancy for this stretch of road, a problem which has been highlighted by the relative ease by which other state highways have been closed due to weather and fire events. These include SH6, which was partially closed between south of Havelock and north of Rai Valley township on Day 2 due to a slip and flooding following heavy rain, and more recently SH7, which was closed for over eight hours due to rural fire on 1st March 2017. Similar challenges exist for a road closure due to a vehicle crash, which becomes more likely with increased traffic flows.

In an attempt to reduce the risk of motor vehicle crashes on SH63, SH6, SH65 and SH7, NZ Transport Agency has increased signage, increased public communication with key messages, installed temporary traffic signals at one bridge, improved delineation, and reduced the speed limit from 100 $\mathrm{km} / \mathrm{h}$ to $80 \mathrm{~km} / \mathrm{h}$, and down to $60 \mathrm{~km} / \mathrm{h}$ through Wairau River township [26]. Police enforcement has also increased, and NZ Transport Agency has also enhanced its response measures.

The additional traffic, particularly heavy truck freight, is causing further travel time delays, as well as accelerated pavement damage resulting in large additional maintenance costs. To increase road capacity, NZ Transport Agency has increased the number of passing bays to increase the number of overtaking opportunities, widened the sealed width of roads, and, on SH63, constructed three new Bailey bridges alongside pre-existing one lane bridges, to allow simultaneous two-way traffic flow [27; 28]. Strengthening of large stretches of the alternative route's pavement was also required, principally on SH63, as it was not originally designed for the traffic loading (diverted from SH1 and as well as diverted rail freight) now travelling the route.

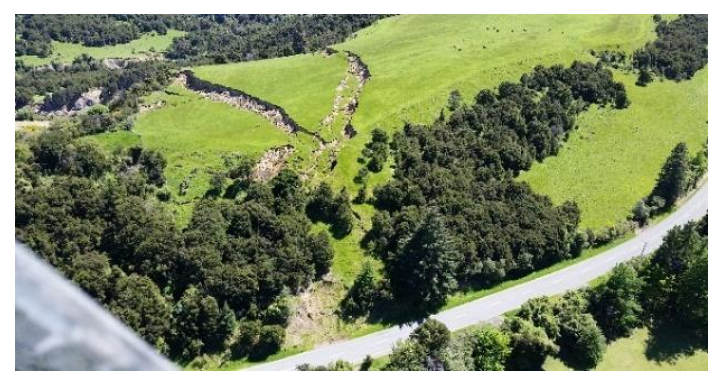

(a) Ruptured ground with increased landslide risk to the road. Photo credit: Aurecon, 2016

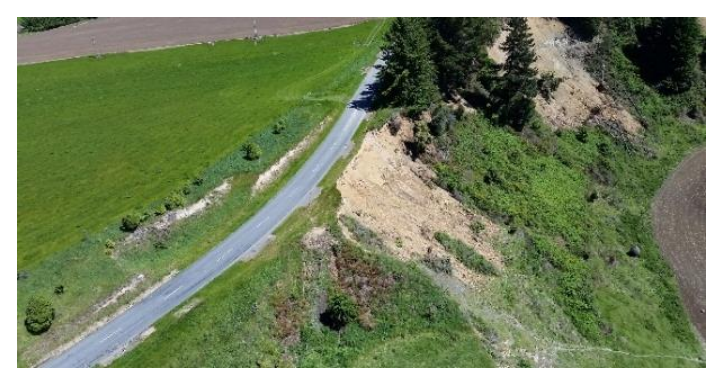

(b) Landslide undercutting road, slumping potential. Photo credit: Aurecon, 2016

Figure 9: Co-seismic impacts.

Rail

The earthquake cost KiwiRail \$12 million from loss of trade to the end of December, and KiwiRail estimates direct costs from loss of trade due to the disruption of the MNL will be around $\$ 25$ million by the end of June 2017. Estimates suggest the total cost to repair the rail line will be approximately $\$ 500$ million (25\% of the total estimated $\$ 2$ billion to restore the transport corridor), although $60-80 \%$ of this cost is likely to be met by KiwiRail insurance [23].

The loss of the rail line caused increased use of the road and shipping networks (Figure 27); since the MNL is an important freight line, KiwiRail's immediate efforts were focussed on minimising the disruption to the New Zealand exporters. This included trucking stock along the alternative state highway route and arranging rail alternatives for Wellington port freight customers to other North Island ports (Figure 27).

To further reduce disruption to freight customers, and to reduce truck congestion on already increased road demands, KiwiRail entered the coastal freight shipping market with a new "NZ Connect" service on Day 15 (with support of Ports of Auckland, Lyttelton Port of Christchurch and ANL Shipping) (Figure 27). Auckland and Christchurch ports expanded operations and rail services were increased from the ports' inland hubs to maximise the effectiveness of the freight route.

The train trapped near Kaikōura was looted [29]. This led to KiwiRail working with the police to better secure the remaining train cargo. On Day 38 , a crane arrived to remove containers off the train, so they could be delivered by road.

Unrelated to the earthquake, a large rural fire closed the Christchurch to Greymouth line on 4th February 2017 (Day 83) (Figure 30), and this did not reopen until 22nd March, further reducing rail capacity within the South Island in the interim. 
North Canterbury Transport Infrastructure Rebuild (NCTIR) Alliance

Following the initial earthquake damage, there was multiagency discussion about whether SH1 and the MNL railway line should be reopened, especially around the most severely damaged section between Mangamaunu and Clarence (Figure 24) $[30 ; 31]$. NZ Transport Agency report that within one to two weeks (following the earthquake), the question of whether to abandon the coastal road and instead develop an alternate route, such as upgrading the Molesworth Track or Rainbow Road, was raised. Both are poor quality, summer-only, roads that already exist. KiwiRail also report discussing possible alternatives, but suggest these were less attractive and realistic than the road alternatives. During these discussions, it quickly became clear that reopening the existing coastal route was the most viable option, for three primary reasons:

1) Distance: the existing coastal route is by far the shortest route.

2) Cost: The existing coastal route would be able to be cleared many times over for the cost of upgrading other routes (which themselves are located in a high hazard risk area).

3) Reliability: regular winter closures versus occasional storm surge closures. Alternatives including the Molesworth Track and Rainbow Road traverse high mountain passes, and so would be closed many times during each winter just with snow and ice events. NZ Transport Agency considers infrequent (even when slightly more damaging) closures preferable to frequent closures.

Accordingly, the Government passed emergency legislation to ensure repairs to the coastal route could be accelerated, and on Day 32, Cabinet (a council of senior Government ministers which formulates Government policy) agreed to fund the works required, which were estimated at a cost of between $\$ 1.4$ billion and $\$ 2$ billion [32]. Following this decision, on Day 38, the Government announced the North Canterbury Transport Infrastructure Rebuild (NCTIR) alliance, between NZ Transport Agency, KiwiRail, Fulton Hogan, Downer, Higgins and HEB Construction [33].

The alliance is responsible for SH1, Route 70, the SH7, SH65, SH6 and SH63 alternative route, and the MNL rail corridor. NCTIR is led by Duncan Gibb, former lead of the Stronger Christchurch Infrastructure Rebuild Team (SCIRT), and was formed to reduce delays caused by tendering for work, and to pool resources to ensure a more cost-effective repair of the rail and road, in the same approach used by SCIRT [33]: this ability to pool resources was a key consideration when considering whether to repair the coastal route or upgrade an alternative.

NCTIR is operating as the lead delivery agency, managing, operating and undertaking all repair, recovery, rebuild and resilience works: where appropriate, NCTIR will take the opportunity to make some strategic resilience investments, such as road shoulder and lane widening, raising the road and/or tracks in areas susceptible to storm surges, and building rockfall and landslide mitigation structures, as can be found elsewhere in New Zealand (Figure 10). The extent to which such resilience measures are implemented is expected to be decided by mid- 2017 .

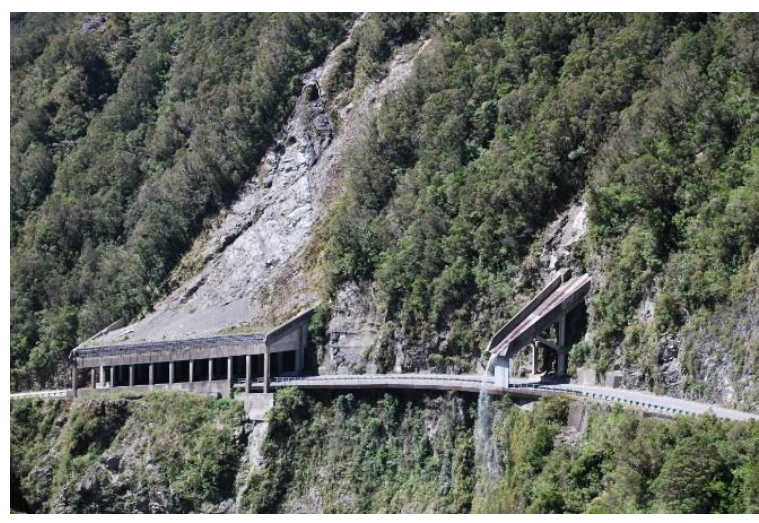

Figure 10: Otira rock fall shelter and aqueduct [34].

\section{Shipping}

Most ports throughout New Zealand were undamaged by the earthquakes, with the major exception of Centreport, Wellington, which suffered substantial damage. Many cargo ships were diverted from Wellington to other ports including Napier, Tauranga and Auckland. This contributed to a doubling of freight demand between Auckland and Christchurch, New Zealand's busiest domestic sea route. A reduction in rail freight capacity also contributed to this increase in demand.

Ferry services between Wellington and Picton resumed by Day 2 (Figure 14), with the only major restriction being for foot passengers, who could not board the ferries due to terminal damage. By Day 4, foot passage was again possible both ways between Wellington and Picton on Bluebridge services (Figure 16), although full Interislander operation did not resume until Day 23 (Figure 21).

Shipping was also used as a key emergency resource for Kaikōura, being used to evacuate 635 people from Kaikōura on HMNZS Canterbury to Lyttleton Port, and provide emergency supplies for the township.

\section{Air}

Immediately following the earthquake, many settlements (including Kaikōura) were inaccessible by land. Therefore, helicopters were extensively used to access these settlements (there was huge demand for helicopter access from civil defence, infrastructure providers, media, scientists and other groups), as well as plane and sea access for Kaikōura, via its small airfield and port. Due to high usage, a five-day Temporary Restricted Area was established around Kaikōura on Day 4, to facilitate safe aircraft operation during the emergency response (Figure 11)

To evacuate tourists (and vulnerable residents) quickly, a "don't come back empty" policy was implemented by CDEM where possible and appropriate. The Emergency Operations Centre in Kaikōura prioritised evacuees, and through this policy, New Zealand Defence Force (NZDF) helicopters delivering emergency supplies to Kaikōura evacuated 198 people by the end of Day 2, and a further 165 by the end of Day 3. Air evacuees were received at Woodend by Waimakariri District Council and a number of agencies, including travel agents, on behalf of Canterbury CDEM.

Private airlines also added flights, providing capacity when other transport modes could not. On Day 2, Air New Zealand operated an additional return flight between Wellington and Marlborough, as ferries were reduced, and, with no road access, SoundsAir operated four flights from Kaikōura to Christchurch and Pelorus Air provided a charter service between Marlborough and Kaikōura (Figure 14). On Day 3 , SoundsAir flew four flights from Kaikōura to Wellington 
(Figure 15). Additionally, on Day 8 (still with no public road access to Kaikōura), SoundsAir launched two temporary daily services, between Kaikōura and Christchurch and Kaikōura and Blenheim (Figure 18). As part of this service, the company also offered to carry the town's postal deliveries on the flights [35]. All these Kaikoura flights were new routes, and were limited to small aircraft, typically carrying 10 passengers, due to the length of the runway. Finally, SoundsAir added additional flights between Christchurch and Blenheim for the Christmas and New Year period, as demand increased due to the long inland road diversion (Figure 21) [36].

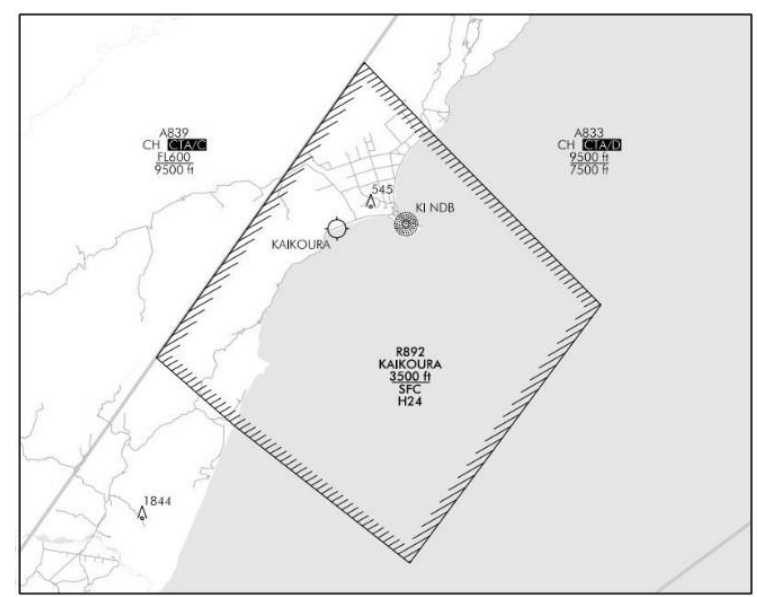

Figure 11: The five-day temporary restricted area (NZR892) established in the Kaikoura area on day 4 [37].

\section{Timeline of Key Transport Events}

A detailed table of key transport events during the first 100 days following the 14th November 2016 is provided in the appendix (Table 1).

The below maps show level-of-service changes between 14th November 2016 (Day 1) to 21st February 2017 (Day 100), for: state highway roads and alternative routes; rail lines and official KiwiRail diversions; Bluebridge and Interislander vehicle and people ferries; and commercial flights between Kaikōura, Christchurch, Wellington, Blenheim, and Picton. Where days are stated without times, the maps show level-ofservice at the end of the day.

The maps are split into two sets. Figures 12 to 24 show state highways and alternative routes, commercial flights and both Bluebridge and Interislander vehicle and passenger ferry services, which provide the main ferry link between the North and South islands between Wellington and Picton. Rail lines and official KiwiRail diversions are displayed separately in Figures 25 to 30 . This is largely because the rail and road network follow similar routes, making it difficult to display them on the same maps. The rail levels-of-service shown are for freight trains only; the daily rail passenger service between Picton and Christchurch has been cancelled until the end of 2017. The rail maps also show the level-of-service for the rail component of the rail-enabled Aratere Interislander ferry (the Aratere also carries vehicles and foot passengers, included in the vehicle and passenger ferry services: Figure 12 to Figure 24).

Level-of-Service Mapping for State Highway Roads and Alternative Routes, Commercial Flights, and Bluebridge and Interislander Vehicle and Passenger Ferries

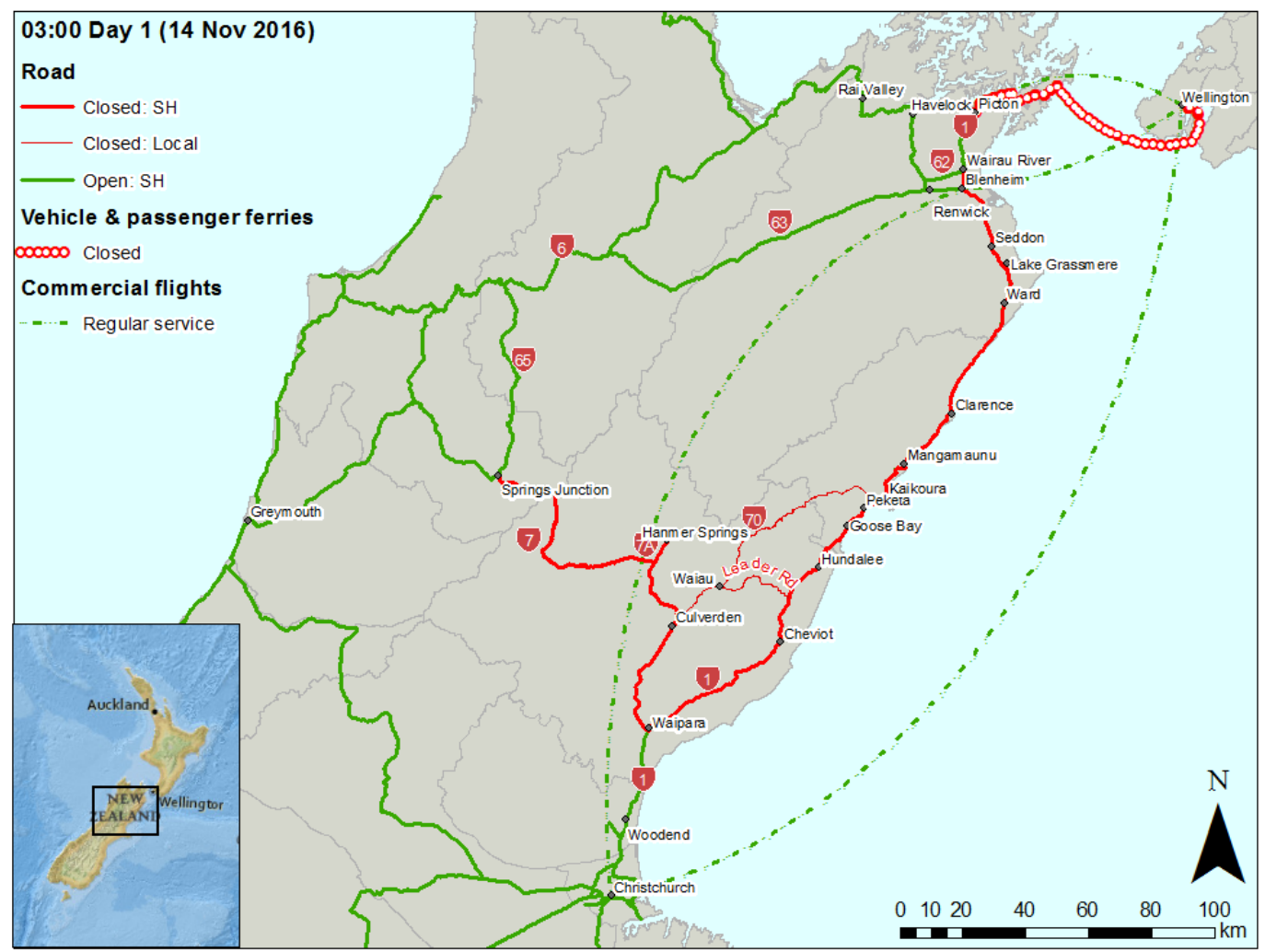

Figure 12: Level-of-service at 03:00 on day $1\left(14^{\text {th }}\right.$ November 2016). 


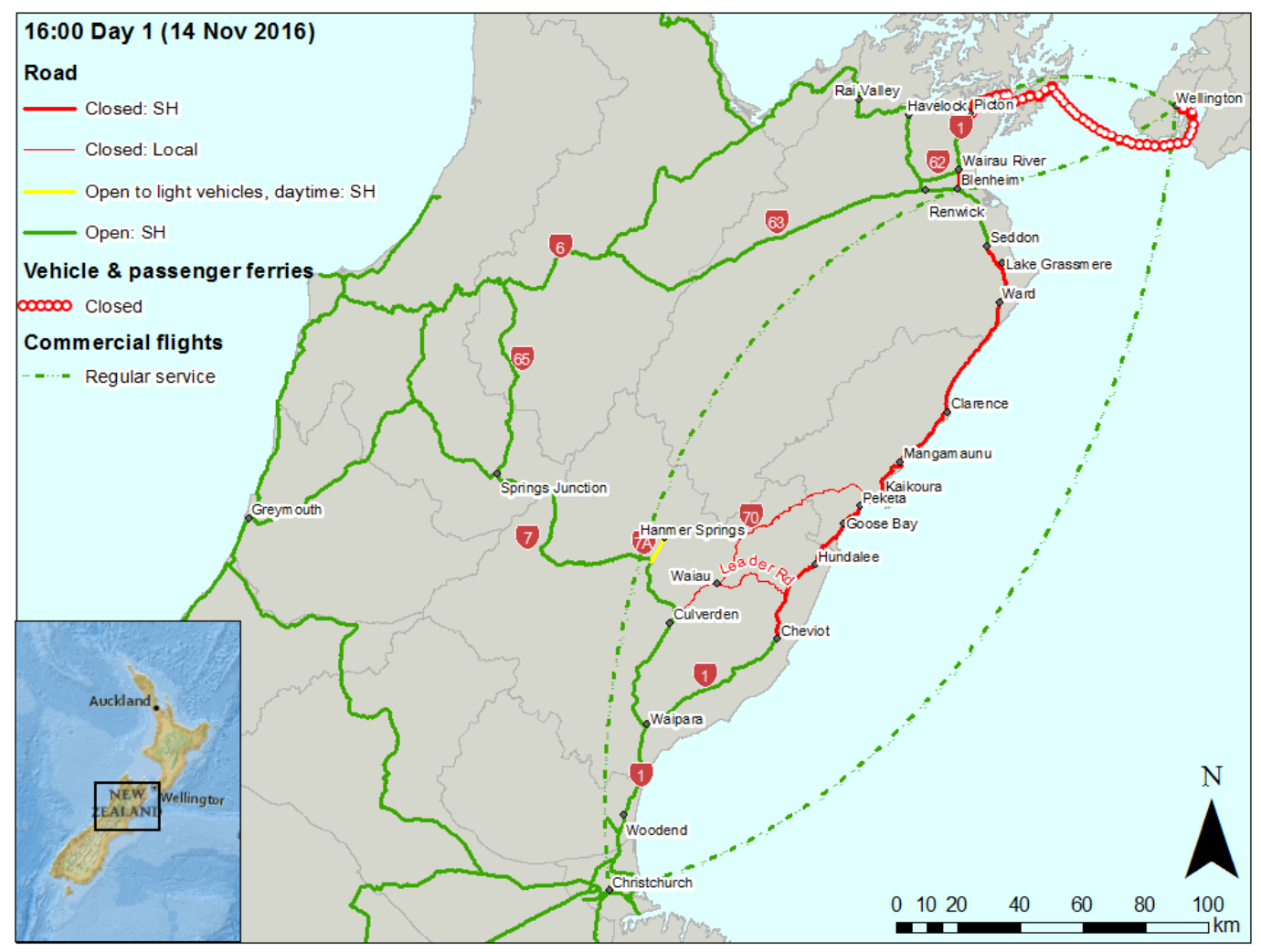

Figure 13: Level-of-service at 16:00 on Day 1 (14 ${ }^{\text {th }}$ November 2016).

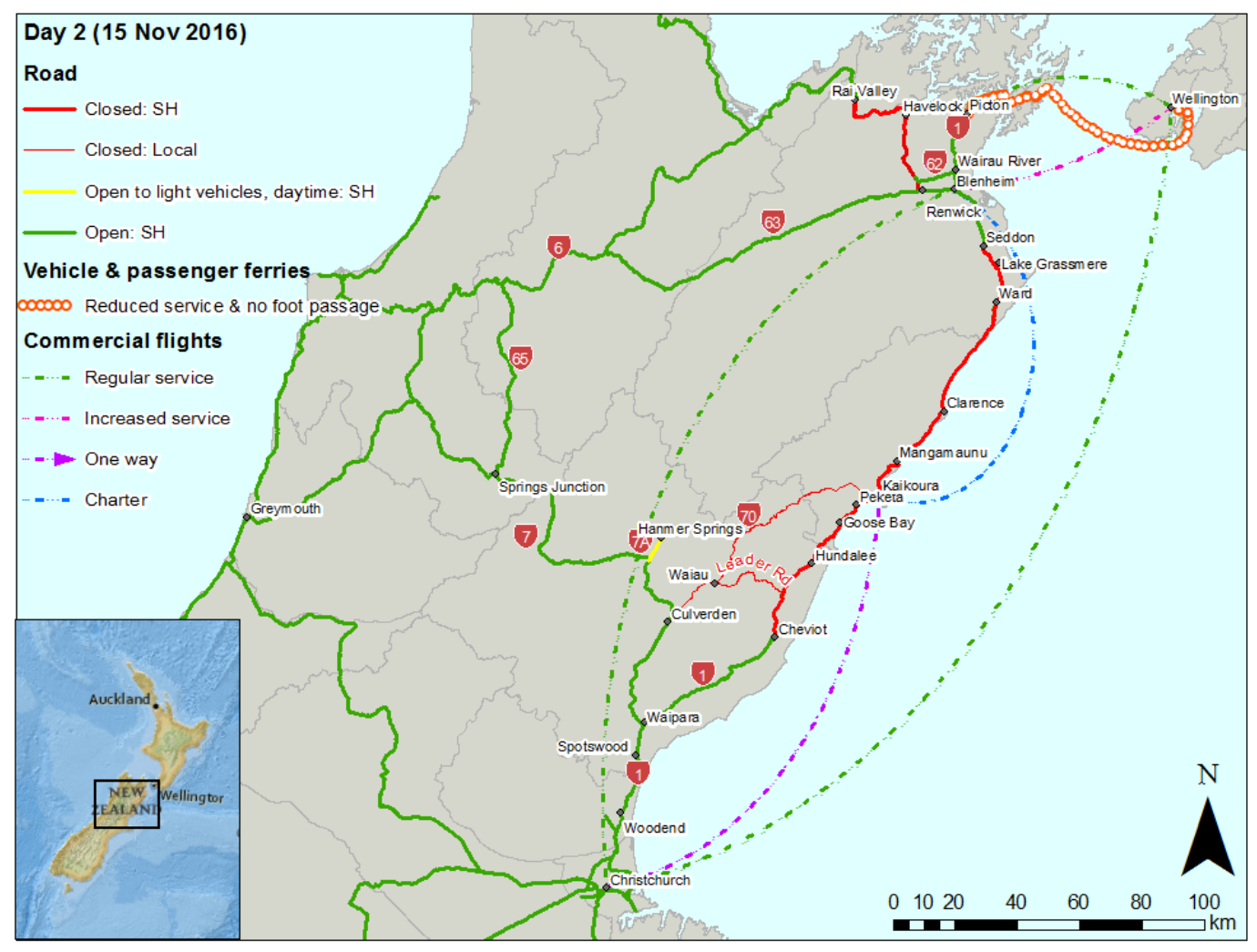

Figure 14: Level-of-service on Day $2\left(15^{\text {th }}\right.$ November 2016). 


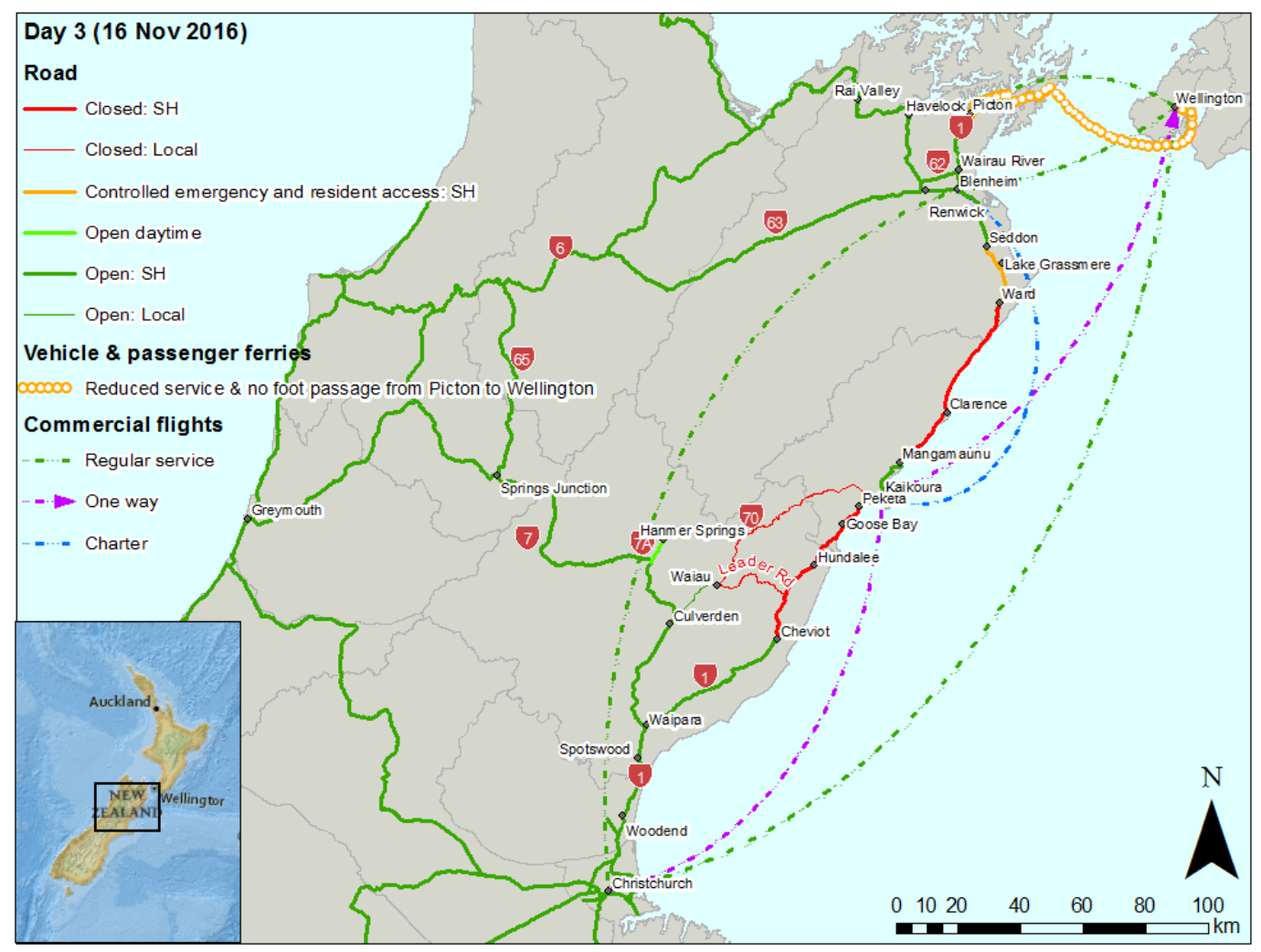

Figure 15: Level-of-service on Day 3 (16 ${ }^{\text {th }}$ November 2016).

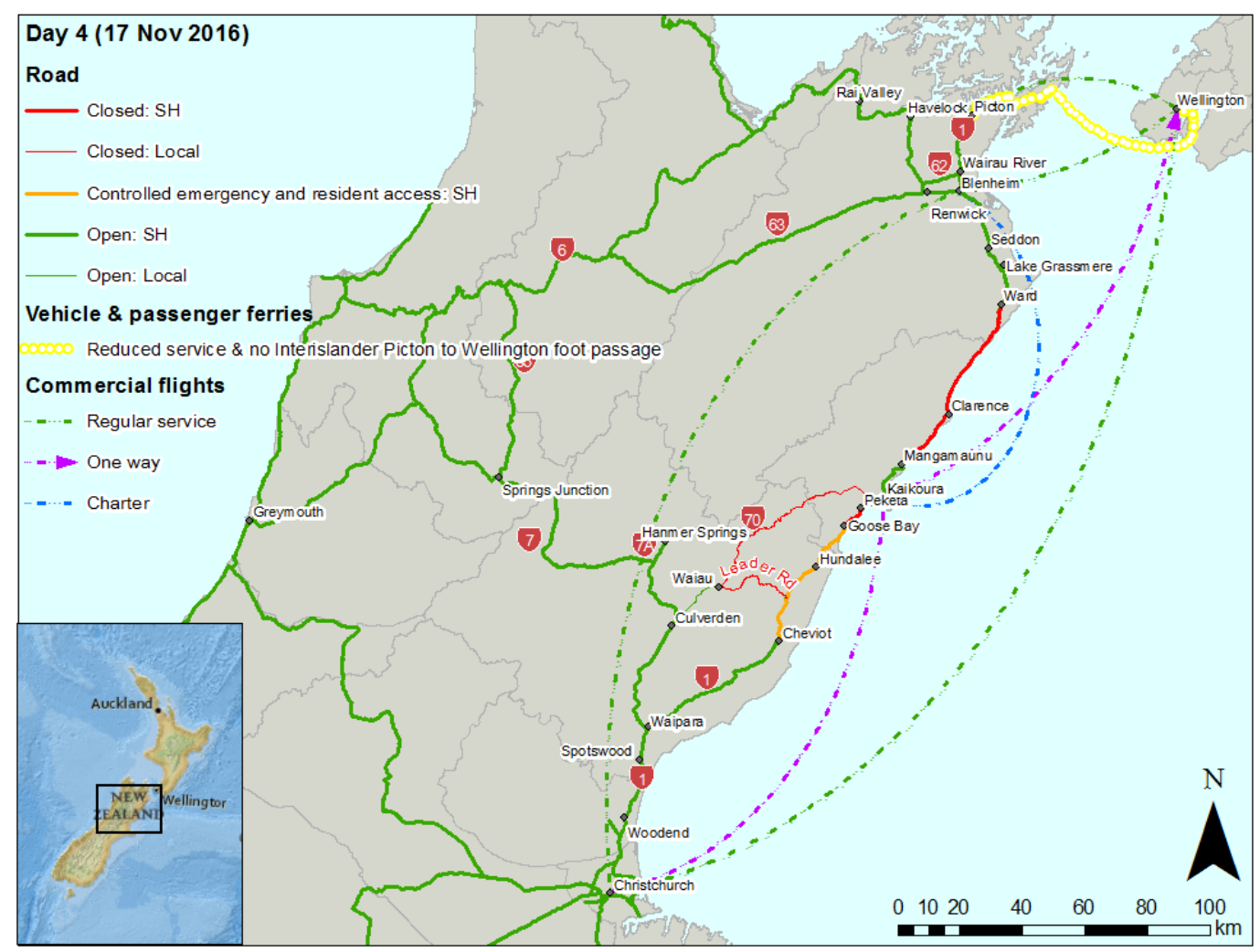

Figure 16: Level-of-service on Day $4\left(17^{\text {th }}\right.$ November 2016). 


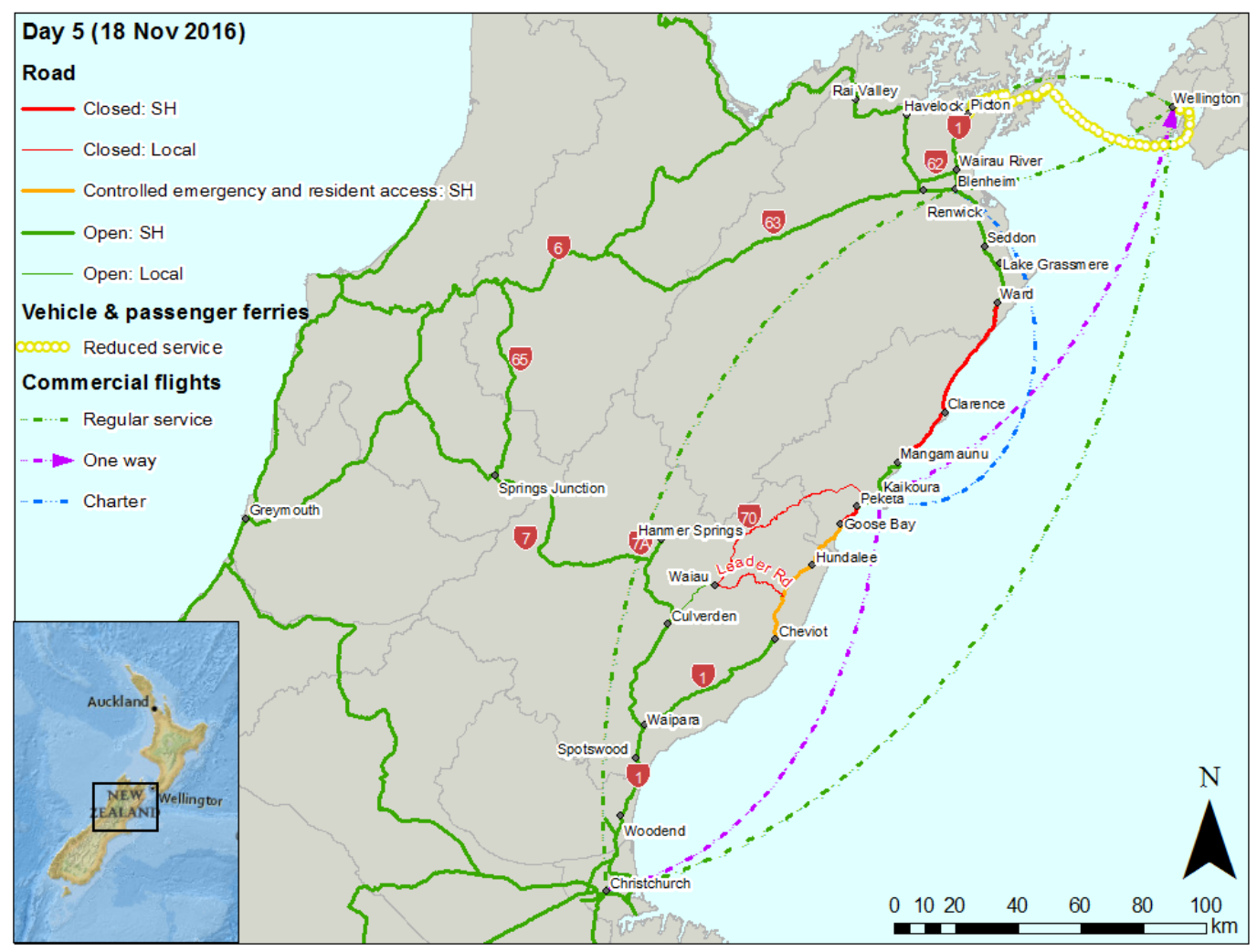

Figure 17: Level-of-service on Day 5 (18 ${ }^{\text {th }}$ November 2016).

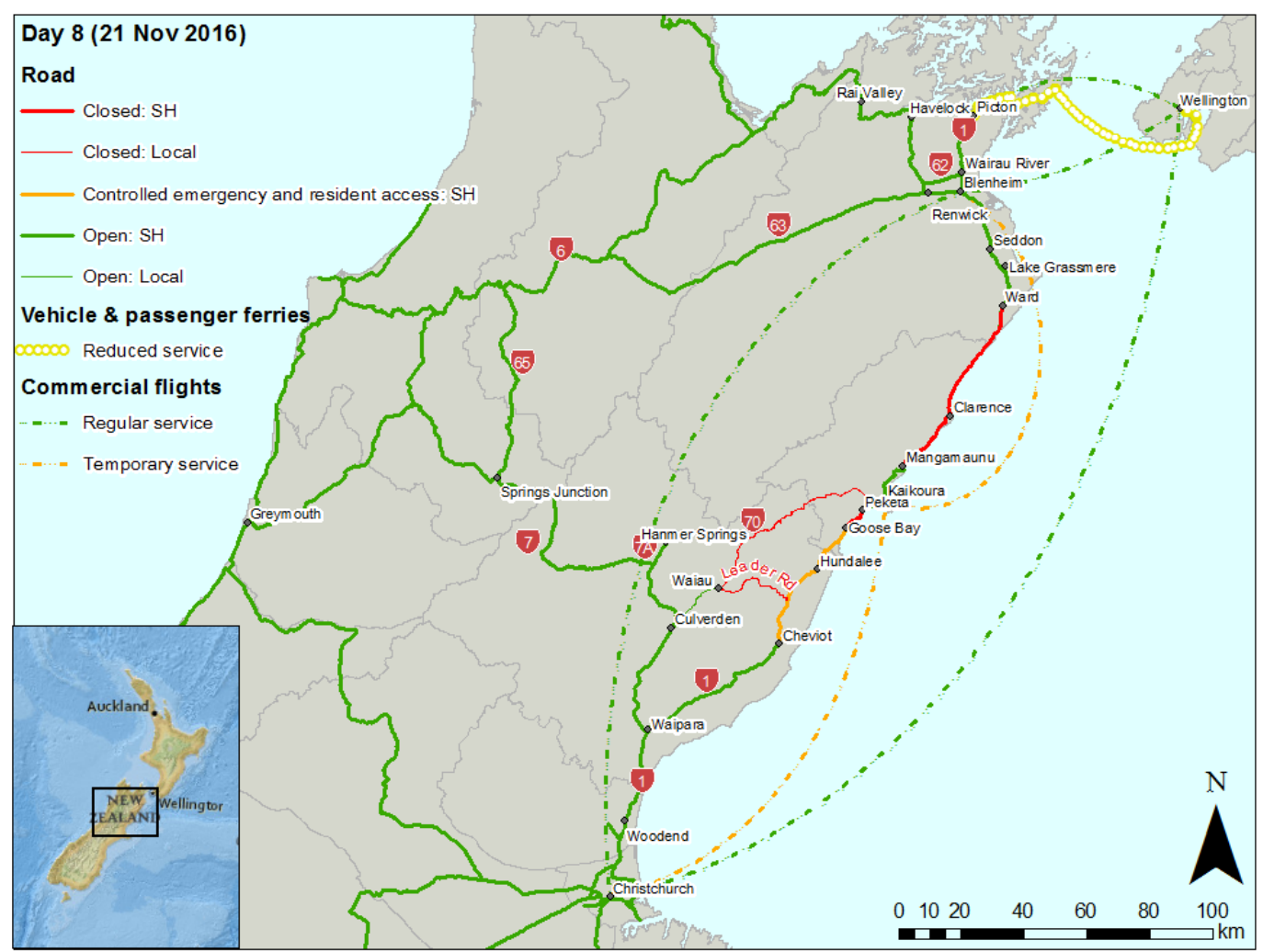

Figure 18: Level-of-service on Day $8\left(21^{\text {st }}\right.$ November 2016). 


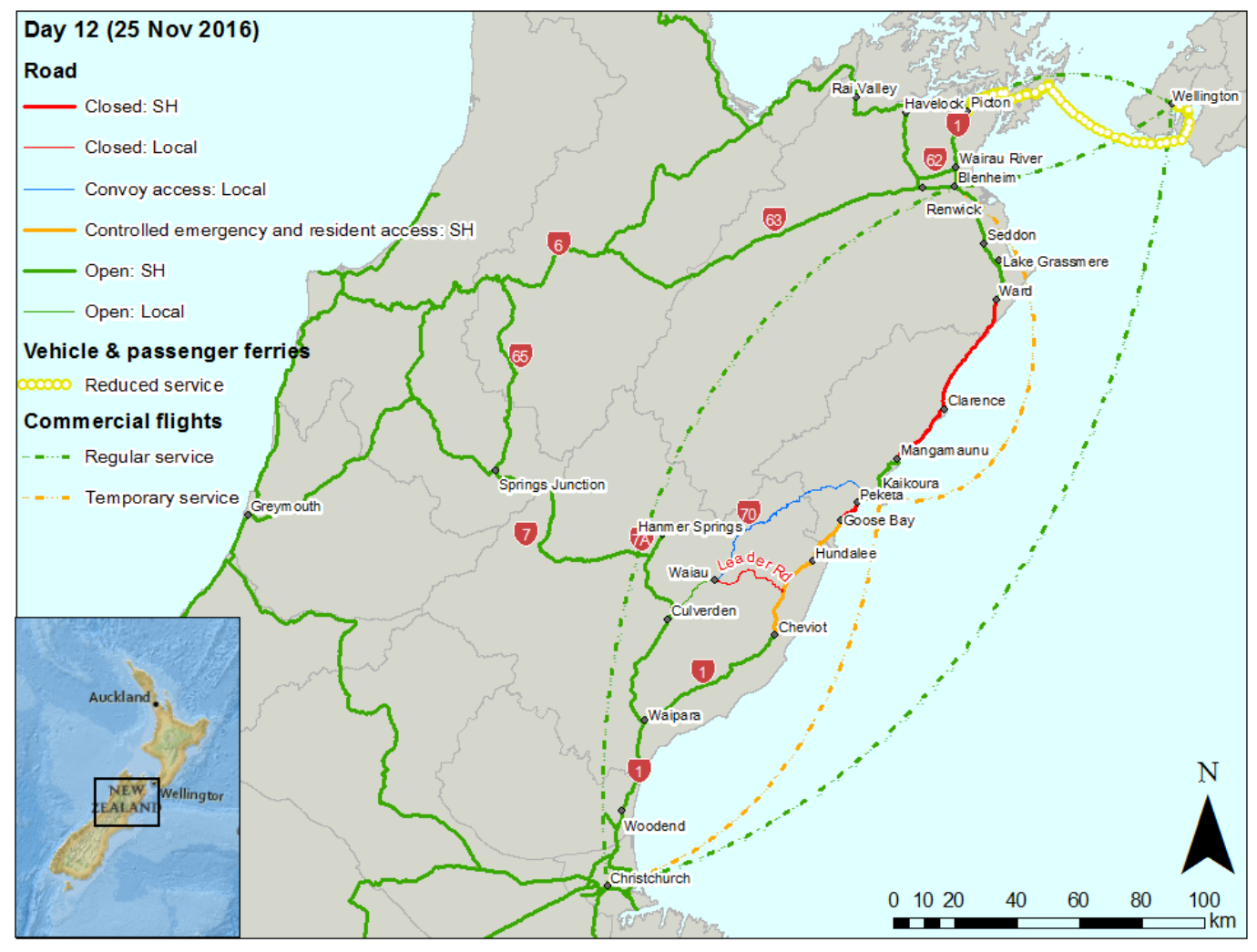

Figure 19: Level-of-service on Day $12\left(25^{\text {th }}\right.$ November 2016).

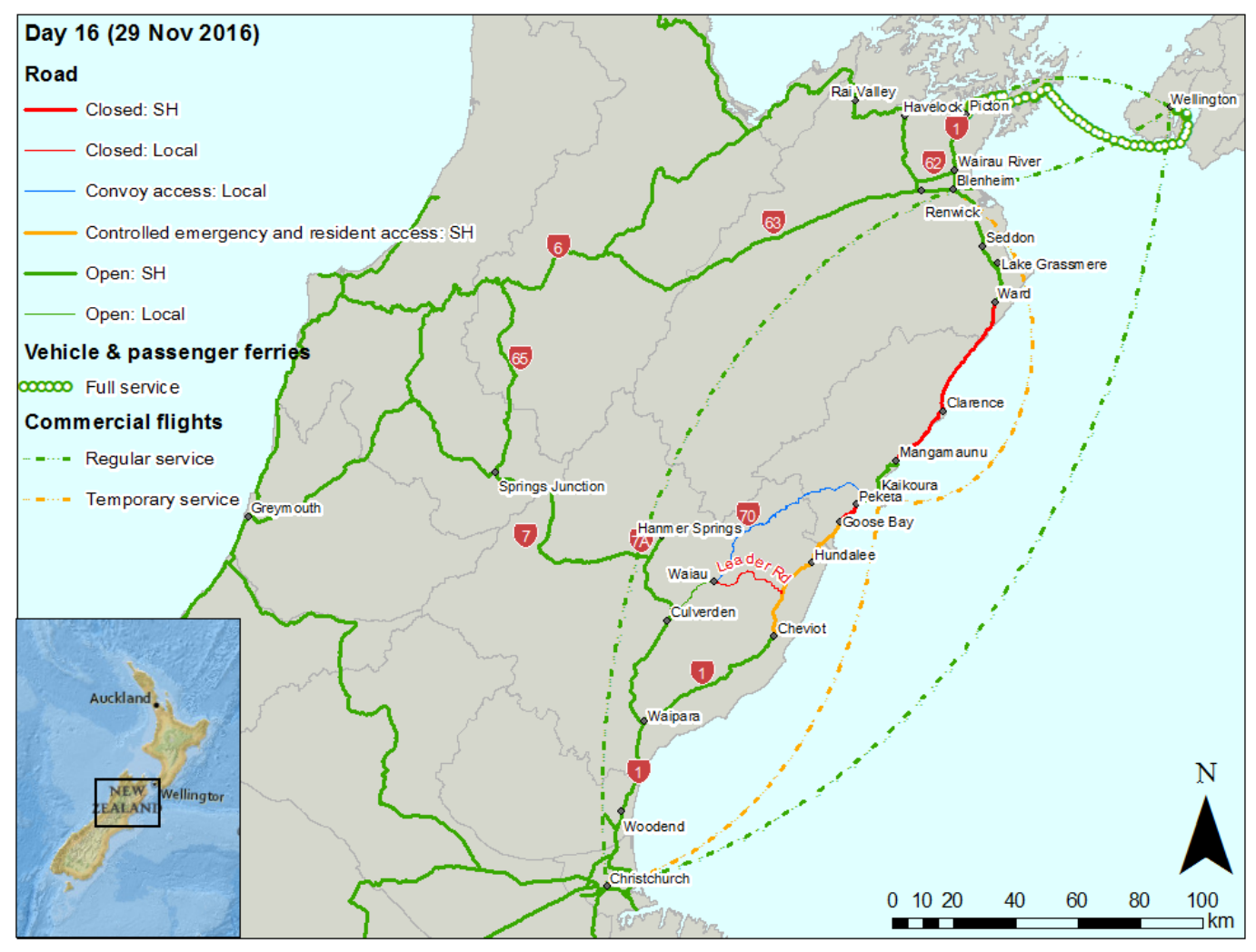

Figure 20: Level-of-service on Day $16\left(29^{\text {th }}\right.$ November 2016). 


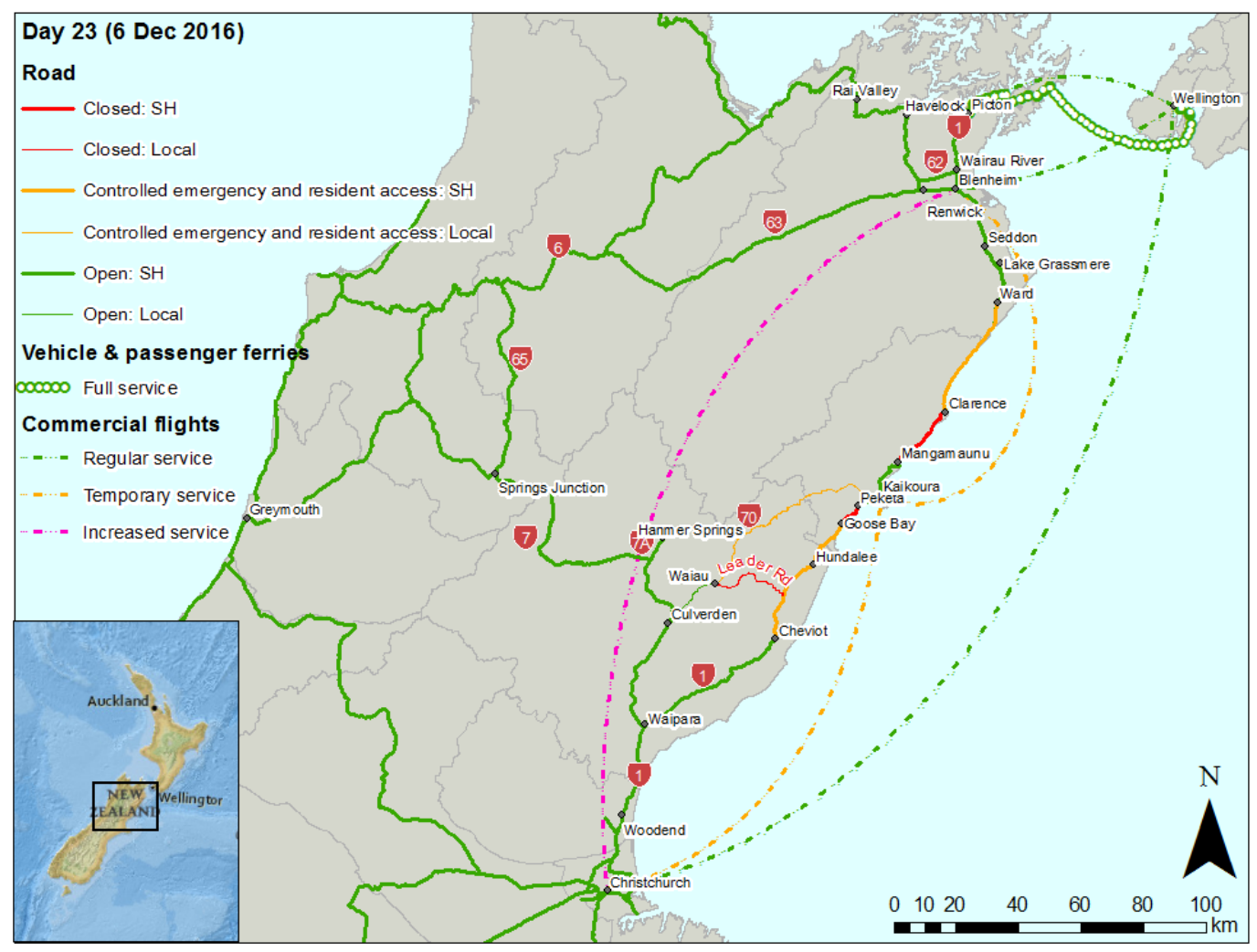

Figure 21: Level-of-service on Day 23 (6 ${ }^{\text {th }}$ December 2016).

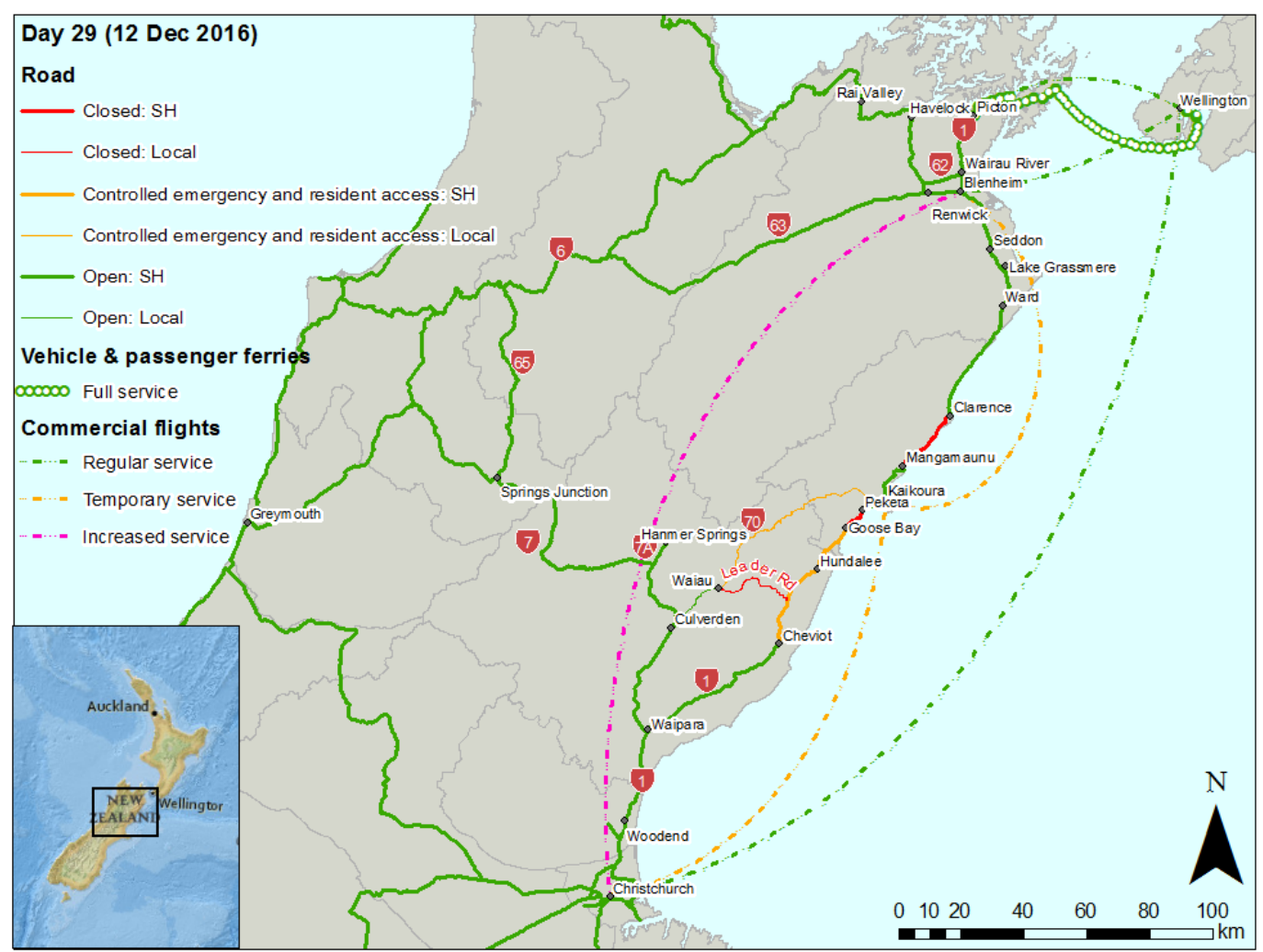

Figure 22: Level-of-service on Day 29 (12 ${ }^{\text {th }}$ December 2016). 


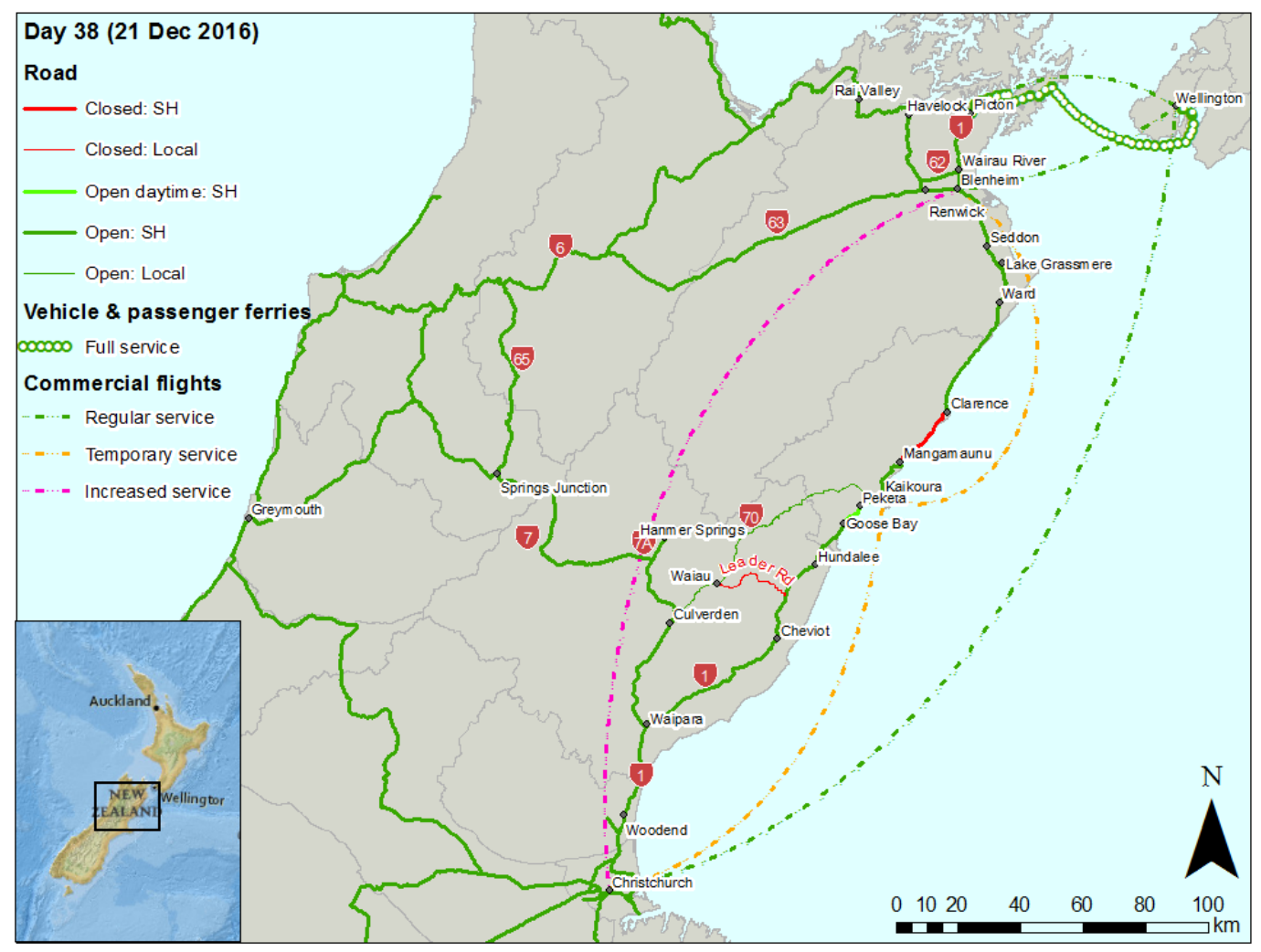

Figure 23: Level-of-service on Day 38 (21 ${ }^{\text {st }}$ December 2016).

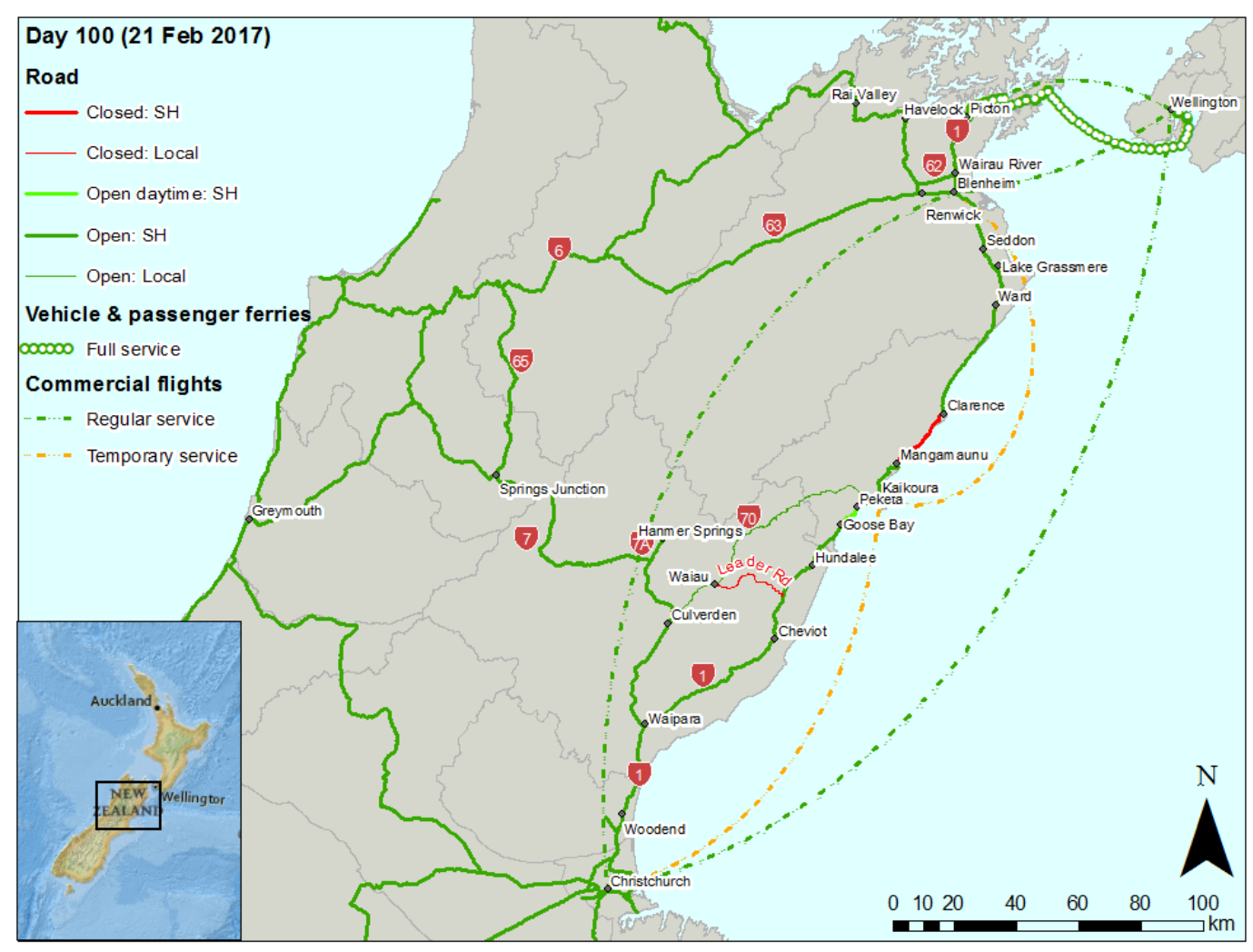

Figure 24: Level-of-service on Day $100\left(21^{\text {st }}\right.$ February 2017). 
Level-of-Service Mapping for Rail Lines Carrying Freight Goods Only, the Rail Component of the Aratere Rail-Enabled Interislander Ferry, and Official KiwiRail Diversions

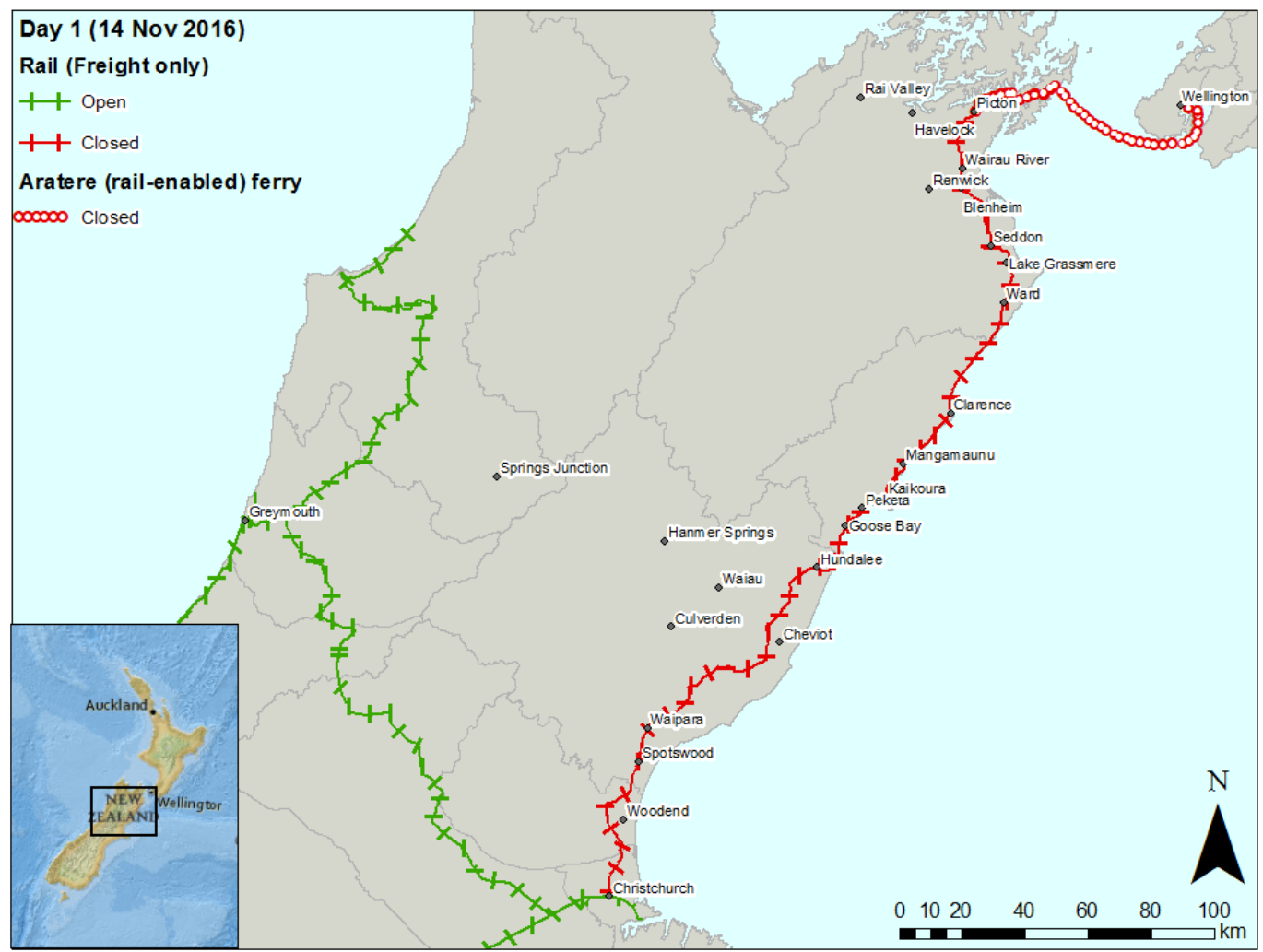

Figure 25: Rail level-of-service on Day $1\left(14^{\text {th }}\right.$ November 2016).

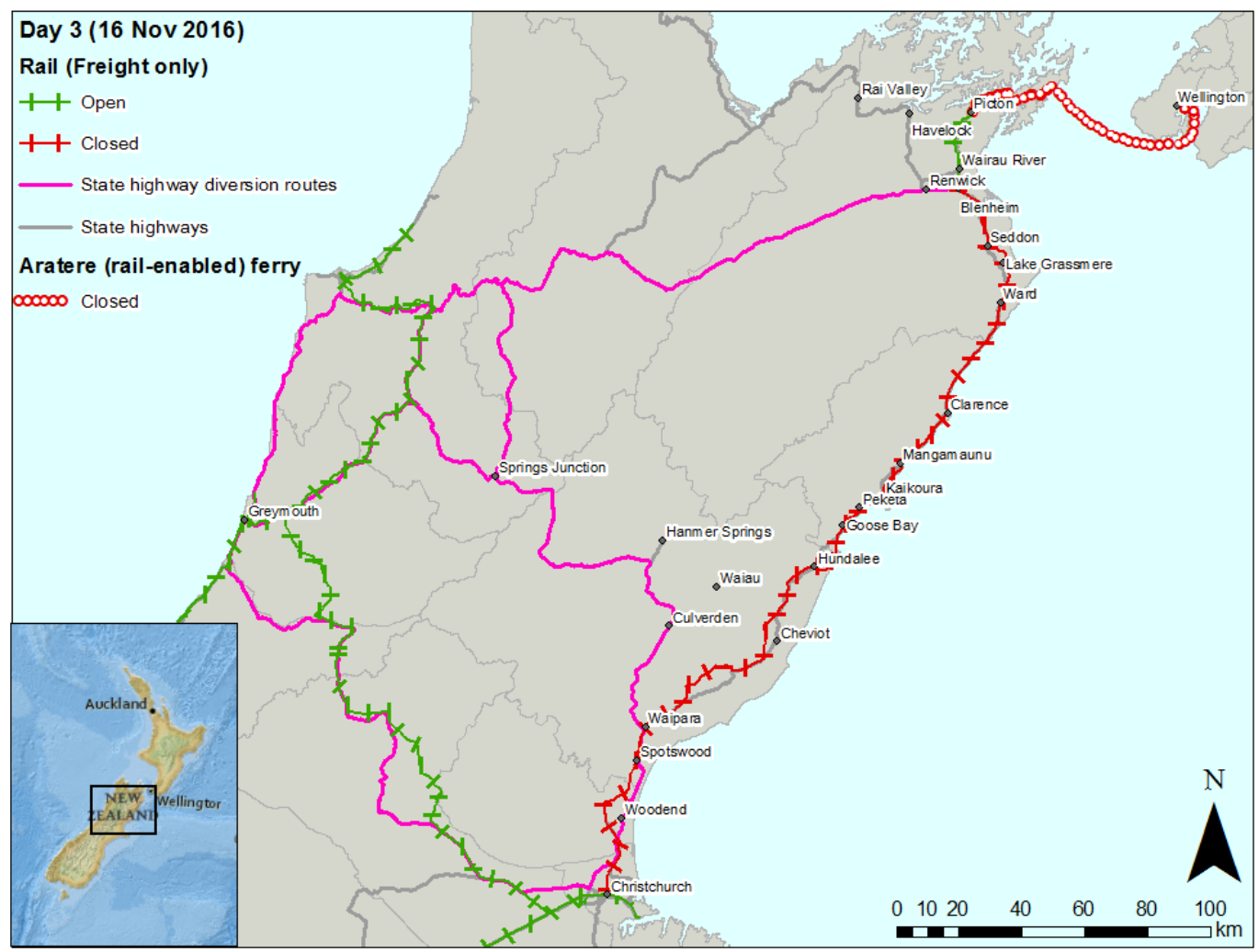

Figure 26: Rail level-of-service on Day 3 (16 ${ }^{\text {th }}$ November 2016). 


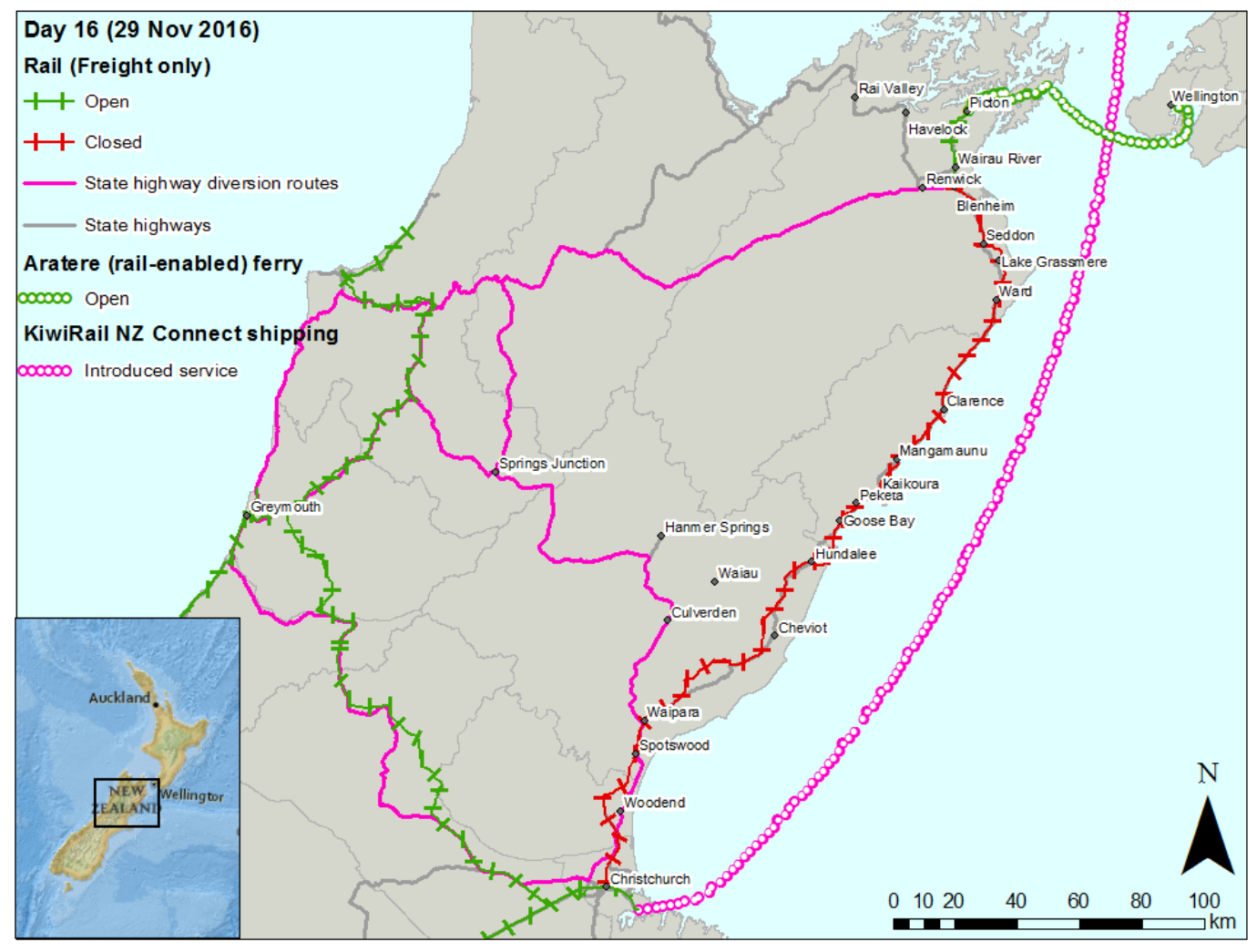

Figure 27: Rail level-of-service on Day $16\left(29^{\text {th }}\right.$ November 2016).

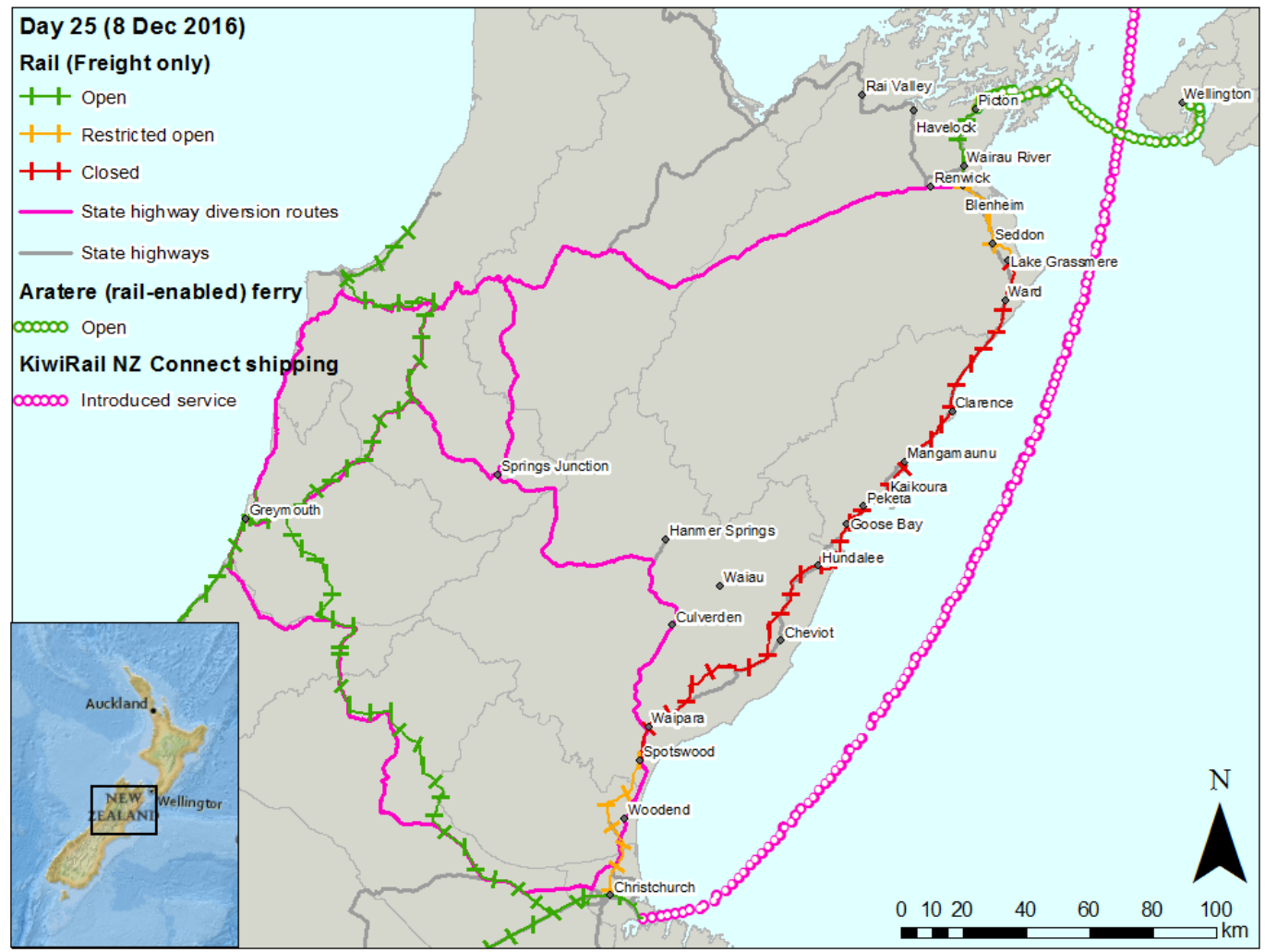

Figure 28: Rail level-of-service on Day 25 ( $8^{\text {th }}$ December 2016). 


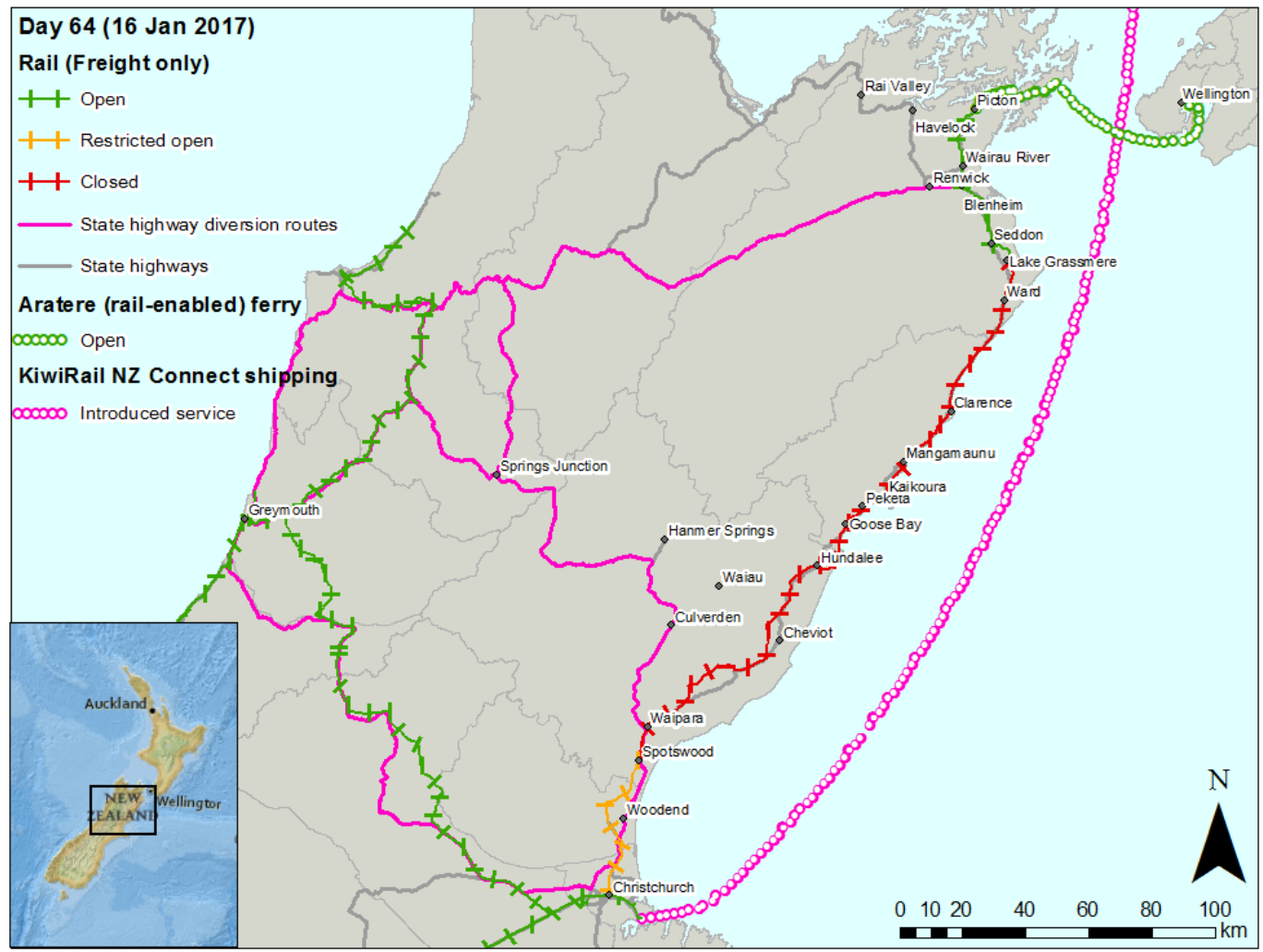

Figure 29: Rail level-of-service on Day 64 (16 ${ }^{\text {th }}$ January 2016).

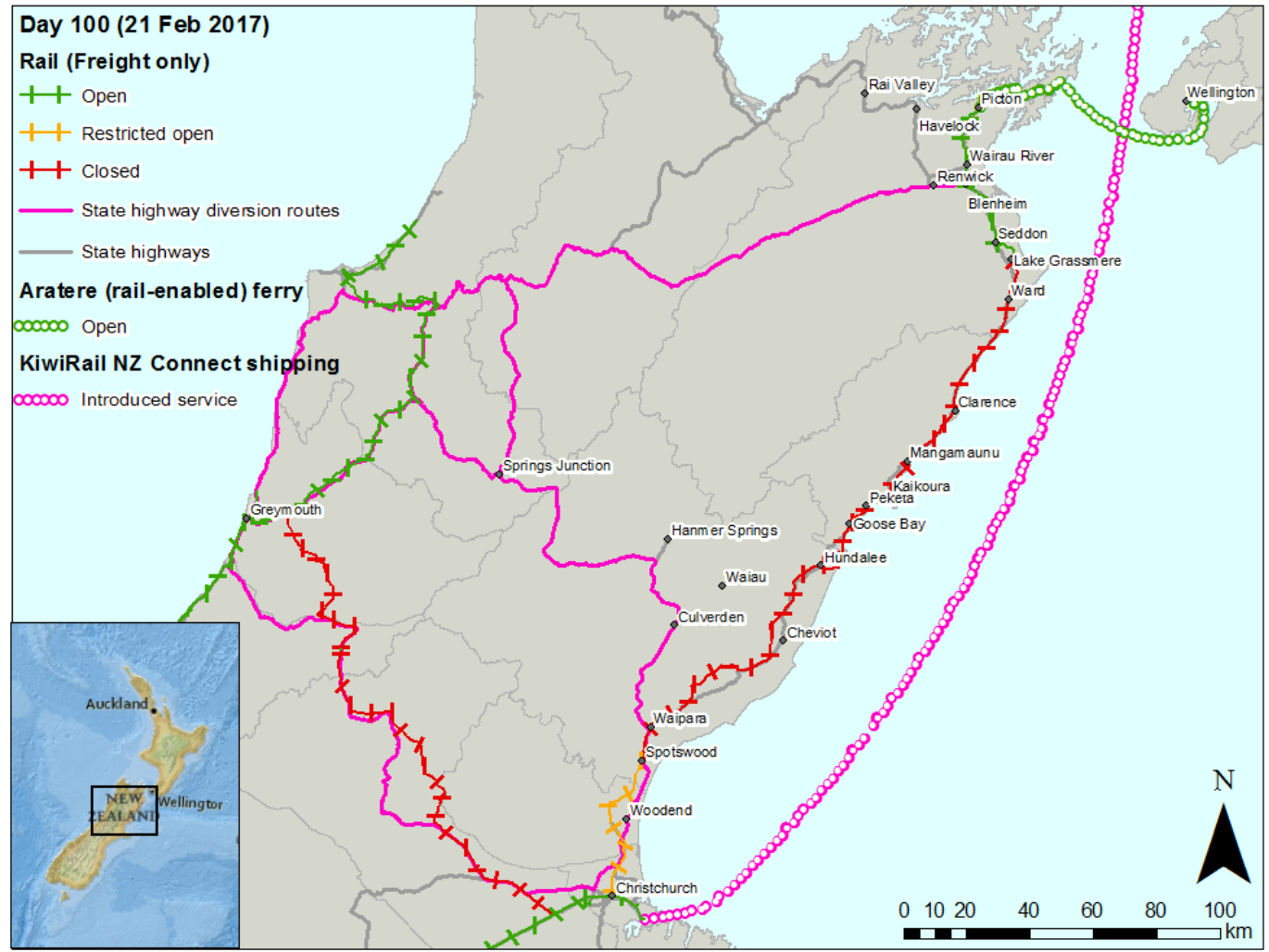

Figure 30: Rail level-of-service on Day 100 (21 ${ }^{\text {st }}$ February 2017). 


\section{DISCUSSION}

\section{National and Regional Response and Resilience}

From the national and regional economy perspective, the earthquake was severe due to the damage to distributed infrastructure, particularly transportation networks: immediately following the earthquake, SH1 was closed between Waipara and Wairau River township, SH7 (including SH7A) was closed between Waipara and Springs Junction, increasing the travel time between Christchurch and Picton from around $3 \frac{1}{2}$ hours to more than 8 hours (Figure 12), all rail services between Palmerston North (North Island, north of Wellington) and Christchurch were suspended (Figure 25), and Picton and Wellington ports were closed, closing the main sea link between the South and North islands. This caused regional impacts, particularly disrupting supply chains [11] However, although there was still substantial strain on the transportation network, by the end of Day 1 access had greatly improved (Figure 13). SH1 had reopened from Waipara to Cheviot and SH7 had reopened between Waipara and Springs Junction (including daytime access along SH7A to Hanmer Springs), meaning the travel time between Christchurch and Picton became around $61 / 2$ hours. All ports were functioning (some at reduced capacity), and alternative cargo transport routes (by air, ferry, and road) remained. By Day 2, extra passenger flights were also being arranged where the usual transport capacity had been reduced below pre-earthquake levels, both between North Island and South Island locations, and between South Island locations (Figure 14).

The event evidenced strong resilient characteristics of the New Zealand transport network, highlighting the value of resilient design, interdependency planning, mutual assistance agreements, and highly trained, adaptable and scalable human resources, encouraged by New Zealand's strong lifelines culture. While the continued closure of critical sections of the country's main highway, SH1, and in particular the loss of rail freight transport along the MNL railway line between Picton and Christchurch, have caused a major national issue in the aftermath of the earthquake, cross-network interdependencies and service provider adaptability have ensured continued transport of goods and people since Day 1. Air and sea transport increased capacity quickly, both for emergency response and to ensure routine transport of goods continued as rail services were substantially reduced. Road transport has been diverted, and although subsequently delayed, has remained operable under increased traffic flows due to the availability of alternative routes and rapid deployment of response measures, facilitating further usage increase from rail diversions. Although these alternative routes are under heavy pressure, these outcomes suggest the NIU's focus on interdependency resilience and whole-of-system improved service, rather than asset, resilience is, at least to a degree, being achieved.

However, whether the current level of regional resilience is acceptable, especially given the unreliability of air and sea travel, remains an important consideration. The rapid deployment of a number of response measures facilitated the SH7, SH65, SH6 and SH63 alternative route to provide sufficient redundancy, but the South Island remains vulnerable as the SH6 section of the alternative route is currently the only route connecting Canterbury, the West Coast, Southland and Otago to the North Island through Picton and Wellington, a problem highlighted by the relative ease by which other state highways have been closed by weather and fire events in recent months within the South Island alone. Additionally, the impact to KiwiRail caused by the closure of one rail line has been immense. The rail network is at present entirely dependent on shipping and road to operate. Without Government ownership and funding, including establishing
NCTIR, the ongoing viability of the rail network would have been questionable; it is worth noting the resilience the government has added in this event.

It is also worth noting that the negative impacts of this event have been reduced by circumstance. While the event caused no transport-related deaths or injuries, had this event occurred during daytime, this almost certainly would not have been the case. Additionally, in the 100 days after the event, the aftershock sequence caused relatively few transportation impacts, allowing for a swifter response and recovery operation. The event also uplifted the land relative to the sea by 1-2 $\mathrm{m}$, itself increasing resilience to future coastal hazards, and reducing damage caused by the tsunami which followed the earthquake (further reduced because the event happened between mid and low tide) [38]

This event has highlighted the vulnerability of New Zealand's regional transportation networks, which have limited or no redundancy in some cases. It is critical to address this issue in the area affected, and in other equally vulnerable regions. High-functioning alternative route redundancy, which can perform if another route or line is damaged (an area NZ Transport Agency had already identified as requiring improvement), is evidently needed [21,39]. Using the road diversion as an example, while the longer route and increased volumes of traffic inevitably increased travel times, travel times along the alternative route could have been improved by pre-event measures including strengthening the pavement to cope with heavier truck loads, placing sufficient passing bays for high volumes of traffic, and building two-way traffic bridges at locations that could become bottlenecks under high traffic flows, instead of implementing these measures postearthquake.

\section{Local Response and Resilience}

The damage to land transport networks caused direct local impacts, including acute isolation of communities. However, the effective response to regional transport challenges allowed CDEM to quickly prioritise access to isolated settlements.

Road access to Kaikōura was first restored through Route 70, due to the heavier damage sustained by SH1. This local road, owned by Hurunui and Kaikōura district councils (Figure 1), was managed by Canterbury CDEM in conjunction with NZ Transport Agency under the declared State of Emergency, as an alternative to the damaged (and closed) state highway. Road management was a balancing act between three priorities: 1. repair of the road; 2. (emergency) supplies for and evacuation from Kaikōura; and 3. access for residents (including farmers). Effective management and operation was critical but challenging as prioritisation of any of the factors slowed down the other two, and the organisational arrangement had never previously been exercised. This led to some (short) operational delays and inconsistent public messaging. NZ Transport Agency took full control of managing Route 70 on Day 16 (29th November 2016), and singularly managed the road until Day 38 , when the Government announced NCTIR, which assumed responsibility for the rebuild of SH1, Route 70 and the MNL rail corridor.

While all settlements had road access by Day 23, CDEM currently advises residents to be prepared with 7 days of emergency supplies. Although helicopter and (to some extent) sea access were sufficient during this event, the event also highlighted the unreliability of these modes of emergency transport. This evidence, along with scenarios being produced for other potential hazardous events, such as an Alpine Fault rupture scenario that suggests air response may be limited [40], mean the length of time without road access seen in Kaikōura could be a realistic example of the length of time people should be prepared to be isolated for. This highlights 
the importance of preparedness, and the gap between recommendations and expected future events.

\section{CONCLUSION}

With increasing reliance on transport networks for vital services, such as just-in-time food and other fast-moving consumer goods delivery, the need for a resilient transport network has never been greater. From the national and regional economy perspective, the 14th November $2016 \mathrm{M}_{\mathrm{w}}$ 7.8 earthquake was severe due to the damage to distributed infrastructure, and particularly transportation networks. 100 days after the event, sections of New Zealand's main highway, State Highway 1 (SH1), and the Main North Line (MNL) railway line between Picton and Christchurch (Figure 1) remain closed, and is the major consequential issue still facing New Zealand. However, cross-network interdependencies and service provider adaptability have ensured continued regional transport of goods and people since Day 1, and this effective response to regional transport challenges allowed CDEM to quickly prioritise access to isolated settlements.

This earthquake, alongside coincident events (such as severe weather and rural fires), highlighted the need for wellpracticed, efficient responses; major strengthening and engineering structures along critical transport routes; and highfunctioning alternative route redundancy, which can perform if another route or line is damaged. This work needs to be evidence-based and should take a holistic view of the essential nature of transportation infrastructure. Settlements were also without road access for 23 days, raising questions of the validity of current CDEM generic advice that residents nationally should be prepared with 7 days of emergency supplies. In rural and potentially isolated communities, advising preparation for a longer period appears necessary.

Much of the groundwork for a resilient transport network was evidenced by this event, but it is important to learn from this, as well as from similar events experienced around the world. This earthquake has highlighted the vulnerability of New Zealand's distributed infrastructure networks, which have little or no redundancy throughout the country. Ensuring the services provided by distributed infrastructure can remain functional after a natural hazard is a critical challenge in order to ensure the future viability of the country, which will face multiple known hazards, some of which will be of greater magnitude than this event, in the future.

\section{ACKNOWLEDGMENTS}

We are thankful to NZ Transport Agency, KiwiRail and Canterbury CDEM for providing data for this paper. We gratefully acknowledge GNS Science, KiwiRail, Tonkin \& Taylor, Aurecon, Dizhur \& Giaretton, and Tim Little for providing images used in this paper. The financial support of the Earthquake Commission (EQC), GNS Science (GNS), the Resilience to Nature's Challenges National Science Challenge, and QuakeCoRE is gratefully acknowledged. This is QuakeCoRE publication number 0171. We are grateful to NZ Transport Agency, KiwiRail, CentrePort, SoundsAir, Canterbury, Marlborough and Wellington CDEM, Marlborough District Council, Kaikōura District Council, Hurunui District Council and Waimakariri District Council for their regular public updates which have contributed to this paper.

\section{REFERENCES}

1 Nicol A, Benson A, Bischoff A, Hatem A, Barrier A, Villamor P, Wandres A, Lukovic B, Hall B, Gasston C, Margetts C, Asher C, Grimshaw C, Madugo C, Fenton C, Hale D, Barrell D, Heron D, Strong D, Townsend D,
Noble DJH, Pettinga J, Kearse J, Williams J, Bensing J, Manousakis J, Borella J, Mountjoy J, Rowland J, Clark K, Pedley K, Sauer K, Berryman K, Hemphill-Haley M, Stirling M, Villeneuve M, Cockroft M, Khajavi N, Griffiths N, Barnes P, Villamor P, Carne R, Langridge R, Zinke R, van Dissen R, McColl S, Cox S, Lawson S, Little T, Stahl T, Cochran U, Toy V, Ries W, Juniper Z, Mouslopoulou V, Oncken O, Begg J, Hamlin I, Kufner S, Reid C, Panagiotis P, Kyritsis S, Beetham D, Kaiser A, Balfour N, Holden C, Fry B, Hamling I, Horspool N, McVerry G, D'Anastasio E, Gerstenberger M, Bannister S, Ristau J, van Houtte C, Abbott E, Hreinsdottir S, Christophersen A, Rhoades D, Benites R, Wotherspoon L, Dellow S, Rosser B, Massey C and della Pascua F (2016). "Geology of the Kaikoura Earthquake". Presentation, University of Canterbury, Christchurch.

2 Stirling MW, Litchfield NJ, Villamor P, Van Dissen RJ, Nicol A, Pettinga J, Barnes P, Langridge RM, Little T, Barrell DJA, Mountjoy J, Ries WF, Rowland J, Fenton C, Hamling I, Asher C, Barrier A, Benson A, Bischoff A, Borella J, Carne R, Cochran UA, Cockroft M, Cox SC, Duke G, Fenton F, Gasston C, Grimshaw C, Hale D, Hall B, Hao KX, Hatem A, Hemphill-Haley M, Heron DW, Howarth J, Juniper Z, Kane T, Kearse J, Khajavi N, Lamarche G, Lawson S, Lukovic B, Madugo C, Manousakis I, McColl S, Noble D, Pedley K, Sauer K, Stahl T, Strong DT, Townsend DB, Toy V, Villeneuve M, Wandres A, Williams J, Woelz S and R. Zinke (2017). "The Mw7.8 2016 Kaikōura earthquake: Surface fault rupture and seismic hazard context". Bulletin of the New Zealand Society for Earthquake Engineering, 50(2): 7384.

3 Hamling IJ, Hreinsdóttir S, Clark K, Elliott J, Liang C, Fielding E, Litchfield N, Villamor P, Wallace L, Wright TJ, D'Anastasio E, Bannister S, Burbidge D, Denys P, Gentle P, Howarth J, Mueller C, Palmer N, Pearson C, Power W, Barnes P, Barrell DJA, Van Dissen R, Langridge R, Little T, Nicol A, Pettinga J, Rowland J and Stirling M (2017). "Complex multifault rupture during the $2016 \mathrm{M}_{\mathrm{w}} 7.8$ Kaikōura earthquake, New Zealand". Science, 356(6334), doi: 10.1126/science.aam7194.

4 Dellow S, Massey C, Cox S, Archibald G, Begg J, Bruce Z, Carey J, Davidson J, Della Pasqua F, Glassey P, Hill M, Jones K, Lyndsell B, Lukovic B, McColl S, Rattenbury M, Read S, Rosser B, Singeisen C, Townsend D, Villamor P, Villeneuve M, Godt J, Jibson R, Allstadt K, Rengers F, Wartman J, Rathje E, Sitar N, Adda A-Z, Manousakis J and Little M (2017). "Landslides caused by the 14 November 2016 Mw7.8 Kaikōura earthquake and the immediate response". Bulletin of the New Zealand Society for Earthquake Engineering, 50(2): 106-116.

5 QuakeCoRE, GEER, and EERI (2017). "M7.8 Kaikōura, New Zealand Earthquake on November 14, 2016". QuakeCoRE, GEER, and EERI, Christchurch, 24pp.

6 Stevenson JR, Becker J, Cradock-Henry N, Johal S, Johnston D, Orchiston C and Seville E (2017). "Economic and social reconnaissance: Kaikōura Earthquake 2016". Bulletin of the New Zealand Society for Earthquake Engineering, 50(2): 346-355.

7 Stats NZ (2013). 2013 Census QuickStats about a place: Christchurch City. http://www.stats.govt.nz/Census/2013census/profile-and-summary-reports/quickstats-about-aplace. aspx ?request_value $=14758 \&$ tabname $=\quad($ accessed 02/05/2017).

8 Bradley, BA, Razafindrakoto HN and Polak V (2017). "Ground-motion observations from the 14 November 2016 $\mathrm{M}_{\mathrm{w}}$ 7.8 Kaikōura, New Zealand, earthquake and insights 
from broadband simulations". Seismological Research Letters, 88(3): 740-756.

9 New Zealand Government (2011). "Connecting New Zealand: A Summary of the Government's Policy Direction for Transport". Ministry of Transport, Wellington, New Zealand, 48pp.

10 KiwiRail (2017). Bridge demolition about to begin. http://www.kiwirail.co.nz/news/464/130/Bridgedemolition-about-to-begin.html (accessed 02/05/2017).

11 Ministry of Transport (2017). "Economic Impact of the 2016 Kaikoura Earthquake: A Report Prepared for the Ministry of Transport". Market Economics, Auckland, 60pp.

12 New Zealand Government (2015). "The Thirty Year New Zealand Infrastructure Plan 2015". National Infrastructure Unit, Wellington, 86pp.

13 The Treasury (2016). "National State of Infrastructure Report 2016: Progress one year on from the Thirty Year New Zealand Infrastructure Plan". National Infrastructure Advisory Board \& the Treasury's National Infrastructure Unit, Wellington, 73pp.

14 Ministry of Civil Defence and Emergency Management (2002). "Civil Defence Emergency Management Act 2002". Ministry of Civil Defence and Emergency Management, Wellington.

15 New Zealand Government (2015). "The Guide to the National Civil Defence Emergency Management Plan 2015". Department of the Prime Minister and Cabinet and Ministry of Civil Defence \& Emergency Management, Wellington, 321pp.

16 Earthquake Commission (2012). "The Value of Lifeline Seismic Risk Mitigation in Christchurch". New Zealand Lifelines, Waikanae, 41pp.

17 New Zealand Lifelines (2007). "New Zealand Lifelines Brochure". New Zealand Lifelines, Waikanae, 4pp.

18 Centre for Advanced Engineering (1997). "Risks \& Realities: A Multi-disciplinary Approach to the Vulnerability of Lifelines to Natural Hazards". Centre for Advanced Engineering, University of Canterbury, 350pp.

19 Giovinazzi S, Wilson T, Davis C, Bristow D, Gallagher M, Schofield A, Villemure M, Eidinger $J$ and Tang A (2011). "Lifelines performance and management following the 22 February 2011 Christchurch earthquake, New Zealand: highlights of resilience". Bulletin of the New Zealand Society for Earthquake Engineering, 44(4): 402-417.

20 KiwiRail (2016). "Annual Integrated Report 2016", KiwiRail, Wellington, 89pp.

21 New Zealand Transport Agency (2014). "State Highway Network Resilience National Programme Business Case: Delivering State Highway Resilience". New Zealand Transport Agency, Wellington, 80pp.

22 Stuff (2016). Plans to fast track deepening of Kaikōura marina. http://www.stuff.co.nz/business/86772819/plansto-fast-track-deepening-of-Kaikōura-marina (accessed 02/05/2017).

23 Radio New Zealand (2017). Insight: Keeping NZ Rail on the Tracks. http://www.radionz.co.nz/national/programmes/insight/au dio/201840329/insight-keeping-nz-rail-on-the-tracks (accessed 02/05/2017).

24 Palermo A, Liu R, Rais A, McHaffie B, Andisheh K, Pampanin S, Gentile R, Nuzzo I, Granerio M, Loporcaro G, McGann C and Wotherspoon LM (2017). "Performance of road bridges during the 14 November 2016 Kaikoura earthquake". Bulletin of the New Zealand Society for Earthquake Engineering, 50(2): 253-270.
25 Cubrinovski M, Bray JD, de la Torre C, Olsen MJ, Bradley BA, Chiaro G, Stocks E and Wotherspoon L (2017). "Liquefaction effects and associated damages observed at the Wellington Centreport from the 2016 Kaikōura earthquake". Bulletin of the New Zealand Society for Earthquake Engineering, 50(2): 152-173.

26 Stuff (2016). New speed limits for alternative Picton to Christchurch highway.

http://www.stuff.co.nz/national/87848488/New-speedlimits-for-alternative-Picton-to-Christchurch-highway (accessed 02/05/2017).

27 Stuff (2017). Building bridges to get over traffic issues on Kaiköura alternative route.

http://www.stuff.co.nz/dominionpost/news/national/89250771/Building-bridges-to-getover-traffic-issues-on-Kaikōura-alternative-route (accessed 02/05/2017)

28 Nelson Live (2017). New Bridges on SH 63 to ease traffic. http://nelsonlive.co.nz/2017/02/new-bridges-on-sh-63-toease-traffic/ (accessed 02/05/2017).

29 The Marlborough Express (2017). Looters describe finding Kaikōura train after earthquake.

http://www.stuff.co.nz/national/89916837/lootersdescribe-finding-Kaikōura-train-after-earthquake (accessed 02/05/2017).

30 The Press (2016). Building transport resilience for the inevitable future disasters. http://www.stuff.co.nz/national/nzearthquake/87053620/building-transport-resilience-forthe-inevitable-future-disasters (accessed 02/05/2017).

31 Nelson Mail (2016). Rainbow road State Highway 1 option floated. http://www.stuff.co.nz/nelsonmail/86860201/rainbow-road-state-highway-1-optionfloated (accessed 02/05/2017).

32 New Zealand Government (2016). Government to reinstate Kaiköura coastal route. https://www.beehive.govt.nz/release/governmentreinstate-Kaikōura-coastal-route (accessed 02/05/2017).

33 New Zealand Government (2016). Alliance established to rebuild Kaikōura coastal route. https://www.beehive.govt.nz/release/alliance-establishedrebuild-Kaikōura-coastal-route (accessed 02/05/2017).

34 Wikimedia Commons (2011). A rock fall shelter and aqueduct on the Arthurs Pass section of New Zealand State Highway 73, near Otira, New Zealand. https://commons.wikimedia.org/wiki/User:Mattinbgn/galle ry_003\#/media/File:Otira_Rock_Fall_Shelter_\%26_Aque duct.JPG (accessed 02/05/2017).

35 The Marlborough Express (2016). Marlborough airline Sounds Air launches new service to Kaikōura. http://www.stuff.co.nz/business/86606248/Marlboroughairline-Sounds-Air-launches-new-service-to-Kaikōura (accessed 02/05/2017).

36 The Marlborough Express (2016). Sounds Air offers additional Christmas flights as travellers look to avoid inland bypass.

http://www.stuff.co.nz/travel/news/87195215/sounds-airoffers-additonal-christmas-flights-as-travellers-look-toavoid-inland-bypass (accessed 02/05/2017).

37 Airshare (2016). Temporary Restricted Area in Place for Kaikōura. $\quad$ https://airshare.uberflip.com/news-hubarticles/temporary-restricted-area-in-place-for-Kaikōura (accessed 02/05/2017).

38 Stuff (2017). Kaiköura Earthquake tsunami was as high as 7 metres at one spot. http://www.stuff.co.nz/national/90773348/Kaikōuraearthquake-tsunami-was-as-high-as-7-metres-at-one-spot (accessed 02/05/2017). 
39 Science Media Centre (2016). Earthquakes and landslides - Expert $Q \& A$.

https://www.sciencemediacentre.co.nz/2016/11/17/earthqu akes-and-landslides-expert-qa/ (accessed 02/05/2017).
40 Robinson TR, Buxton R, Wilson TM, Cousins WJ and Christophersen AM (2015). "Multiple infrastructure failures and restoration estimates from an Alpine Fault earthquake: Capturing modelling information for MERIT". The Economics of Resilient Infrastructure Research Report, Issue 4, 89pp. 


\begin{tabular}{|l|l|}
\hline \multicolumn{2}{|l|}{ Table key } \\
\hline & Hazardous Event \\
\hline & Road \\
\hline & Rail \\
\hline & Air \\
\hline & Shipping \\
\hline
\end{tabular}

\begin{tabular}{|c|c|c|c|c|c|}
\hline \multicolumn{6}{|c|}{ Table 1. Kaiköura earthquake timeline: key transport events. } \\
\hline Date & $\begin{array}{l}\text { Event } \\
\text { Day }\end{array}$ & Day & Time & Event & Source \\
\hline \multicolumn{6}{|c|}{ DAY 1: Monday 14th November 2016} \\
\hline $14 / 11 / 2016$ & 1 & Mon & 0:02 & $\mathrm{M}_{\mathrm{w}} 7.8$ earthquake. & Canterbury CDEM \\
\hline $14 / 11 / 2016$ & 1 & Mon & $2: 34$ & Wairau River Bridge to Waipara (SH1) closed. & $\begin{array}{l}\text { Marlborough CDEM, } \\
\text { NZ Transport Agency }\end{array}$ \\
\hline $14 / 11 / 2016$ & 1 & Mon & & Waipara to Springs Junction (SH7) closed. & NZ Transport Agency \\
\hline $14 / 11 / 2016$ & 1 & Mon & & $\begin{array}{l}\text { Culverden to Kaikōura (Route 70) closed under Civil } \\
\text { Defence Emergency Management act. }\end{array}$ & $\begin{array}{l}\text { Canterbury CDEM, } \\
\text { NZ Transport Agency }\end{array}$ \\
\hline $14 / 11 / 2016$ & 1 & Mon & & $\begin{array}{l}\text { The Main North Line between Picton and Christchurch is } \\
\text { closed. }\end{array}$ & KiwiRail \\
\hline $14 / 11 / 2016$ & 1 & Mon & & $\begin{array}{l}\text { All ferry sailings cancelled until Wellington and Picton } \\
\text { ferry terminals are inspected and cleared to re-open. }\end{array}$ & KiwiRail \\
\hline $14 / 11 / 2016$ & 1 & Mon & & $\begin{array}{l}\text { The rail-enabled Aratere Interislander ferry not shipping, } \\
\text { pending clearance of the Wellington rail span. }\end{array}$ & KiwiRail \\
\hline $14 / 11 / 2016$ & 1 & Mon & 6:00 & $\begin{array}{l}\text { Picton to Blenheim (SH1) only open for Class } 1 \text { vehicles, } \\
\text { up to } 50 \mathrm{~kg} \text {. Heavier vehicles backed up for several } \\
\text { kilometres along the highway. }\end{array}$ & Marlborough CDEM \\
\hline $14 / 11 / 2016$ & 1 & Mon & $10: 15$ & $\begin{array}{l}\text { Diversion around Wairau River Bridge in place on SH1, } \\
\text { via SH62 and SH6. }\end{array}$ & NZ Transport Agency \\
\hline $14 / 11 / 2016$ & 1 & Mon & 13:00 & Lyttleton and timaru ports reopen. & Canterbury CDEM \\
\hline $14 / 11 / 2016$ & 1 & Mon & 14:00 & $\begin{array}{l}\text { Engineers on site at Wairau River Bridge, which remains } \\
\text { closed. }\end{array}$ & Marlborough CDEM \\
\hline $14 / 11 / 2016$ & 1 & Mon & $15: 22$ & Waipara to Cheviot (SH1) open. & NZ Transport Agency \\
\hline $14 / 11 / 2016$ & 1 & Mon & $15: 25$ & Blenheim to Seddon (SH1) open. & NZ Transport Agency \\
\hline $14 / 11 / 2016$ & 1 & Mon & $15: 30$ & SH7A open to light vehicles, will close again at 8pm. & NZ Transport Agency \\
\hline $14 / 11 / 2016$ & 1 & Mon & $15: 59$ & Waipara to Springs Junction (SH7) open. & NZ Transport Agency \\
\hline $14 / 11 / 2016$ & 1 & Mon & $16: 00$ & $\begin{array}{l}\text { Kaikōura airfield functional and operating. Priority is to } \\
\text { get tourists out of Kaikōura. }\end{array}$ & Canterbury CDEM \\
\hline $14 / 11 / 2016$ & 1 & Mon & $17: 00$ & Supplies have started arriving in Kaikōura by helicopter. & Canterbury CDEM \\
\hline $14 / 11 / 2016$ & 1 & Mon & 20:00 & SH7A closed for repairs. & NZ Transport Agency \\
\hline $14 / 11 / 2016$ & 1 & Mon & $20: 00$ & $\begin{array}{l}\text { The Wairau River Bridge is expected to reopen this } \\
\text { evening. Emergency vehicles only are cleared on SH1 } \\
\text { south of Seddon. Fuel is being supplied to Seddon } \\
\text { residents. }\end{array}$ & Marlborough CDEM \\
\hline $14 / 11 / 2016$ & 1 & Mon & & $\begin{array}{l}\text { Wellington Port ferries operating, many cargo ships are } \\
\text { diverting to ports including Napier, Tauranga and } \\
\text { Auckland. }\end{array}$ & CentrePort \\
\hline \multicolumn{6}{|c|}{ DAY 2: Tuesday 15th November 2016} \\
\hline $15 / 11 / 2016$ & 2 & Tue & 6:00 & Work begins to clear SH1 to Kaikoura from the south. & Canterbury CDEM \\
\hline $15 / 11 / 2016$ & 2 & Tue & $7: 54$ & $\begin{array}{l}\text { SH7A open to light vehicles. No towing. There is a } \\
\text { stop/go sign at the Waiau River bridge. }\end{array}$ & NZ Transport Agency \\
\hline $15 / 11 / 2016$ & 2 & Tue & $8: 30$ & $\begin{array}{l}\text { SH6 is closed from north of Rai Valley township to } 7 \mathrm{~km} \\
\text { south of Havelock: Rai Valley township has been isolated } \\
\text { by flooding on one side and a slip on the other. SH63 } \\
\text { remains open but has surface flooding. }\end{array}$ & Marlborough CDEM \\
\hline $15 / 11 / 2016$ & 2 & Tue & $9: 45$ & $\begin{array}{l}\text { Route } 70 \text { being investigated as alternate route to access } \\
\text { Kaikoura. }\end{array}$ & Canterbury CDEM \\
\hline $15 / 11 / 2016$ & 2 & Tue & & $\begin{array}{l}\text { Air New Zealand is operating scheduled flights from } \\
\text { Marlborough. }\end{array}$ & Marlborough CDEM \\
\hline 15/11/2016 & 2 & Tue & & $\begin{array}{l}\text { Air New Zealand is operating an additional return service } \\
\text { between Wellington and Marlborough today to increase } \\
\text { capacity. }\end{array}$ & Marlborough CDEM \\
\hline
\end{tabular}




\begin{tabular}{|c|c|c|c|}
\hline $15 / 11 / 2016$ & 2 & Tue & \\
\hline $15 / 11 / 2016$ & 2 & Tue & \\
\hline 15/11/2016 & 2 & Tue & \\
\hline $15 / 11 / 2016$ & 2 & Tue & \\
\hline $15 / 11 / 2016$ & 2 & Tue & $16: 45$ \\
\hline $15 / 11 / 2016$ & 2 & Tue & 23:59 \\
\hline
\end{tabular}

"First few days"
SoundsAir fly four (10-person) flights from Kaikōura to Christchurch.

Pelorus Air are providing a charter service between Marlborough and Kaikōura.

Two out of three Interislander ferries (the Kaiarahi and Kaitaki) begin carrying freight and vehicle passengers only. Foot traffic passengers are suspended due to terminal damage.

KiwiRail has set up coordination centres in Christchurch and Wellington to enable a closer working relationship with NZ Transport Agency as work continues to assess the damage to the Main North Line and SH1.

Rai Valley to Renwick (SH6) open.

198 people evacuated from Kaikōura via NZDF helicopters.

Army convoys travel through to Kaikōura. Critical infrastructure vehicles allowed through later.
The Marlborough Express

Marlborough CDEM

KiwiRail

KiwiRail

NZ Transport Agency

Canterbury CDEM

Canterbury CDEM

DAY 3: Wednesday 16th November 2016

\begin{tabular}{|c|c|c|c|c|c|}
\hline $16 / 11 / 2016$ & 3 & Wed & $6: 00$ & HMNZS Wellington and Canterbury arrive at Kaikōura. & Canterbury CDEM \\
\hline $16 / 11 / 2016$ & 3 & Wed & $10: 48$ & $\begin{array}{l}\text { SH7A Open (no restrictions), will close at } 8 \mathrm{pm} \text { for } \\
\text { repairs. Expected to be reopened by } 7 \mathrm{am} .\end{array}$ & NZ Transport Agency \\
\hline $16 / 11 / 2016$ & 3 & Wed & & Culverden to Waiau (Route 70) reopens. & NZ Transport Agency \\
\hline $16 / 11 / 2016$ & 3 & Wed & & Mangamaunu to Peketa (SH1, via Kaikōura) reopens. & NZ Transport Agency \\
\hline $16 / 11 / 2016$ & 3 & Wed & & Picton to Ward (SH1) open. & NZ Transport Agency \\
\hline $16 / 11 / 2016$ & 3 & Wed & & $\begin{array}{l}\text { Photo ID required to travel South of Seddon on SH1 } \\
\text { while the emergency operation is underway. }\end{array}$ & Marlborough CDEM \\
\hline $16 / 11 / 2016$ & 3 & Wed & & $\begin{array}{l}\text { Intercity Coach resumes Nelson to Picton service, begins } \\
\text { Christchurch to Picton service via SH7, SH65, SH6 and } \\
\text { SH63. }\end{array}$ & Marlborough CDEM \\
\hline $16 / 11 / 2016$ & 3 & Wed & & $\begin{array}{l}\text { All freight lines in the North Island and south of } \\
\text { Christchurch are open and operating. }\end{array}$ & KiwiRail \\
\hline $16 / 11 / 2016$ & 3 & Wed & & $\begin{array}{l}\text { Freight is being delivered to the container transfer site at } \\
\text { Blenheim and then by truck to Christchurch, either via } \\
\text { SH63, SH6, SH65 and SH7 or the West Coast region. }\end{array}$ & KiwiRail \\
\hline $16 / 11 / 2016$ & 3 & Wed & & $\begin{array}{l}\text { Burnham Whard (Wellington) reopened for shipping } \\
\text { services. }\end{array}$ & CentrePort \\
\hline $16 / 11 / 2016$ & 3 & Wed & $12: 00$ & Leader Road closed & NZ Transport Agency \\
\hline $16 / 11 / 2016$ & 3 & Wed & $14: 30$ & $\begin{array}{l}\text { HMNZS Canterbury loading } \sim 380 \text { people for evacuation } \\
\text { to Christchurch. }\end{array}$ & Canterbury CDEM \\
\hline $16 / 11 / 2016$ & 3 & Wed & & $\begin{array}{l}\text { SoundsAir flies four flights from Kaikōura to Wellington } \\
\text { (10-person flights). }\end{array}$ & $\begin{array}{l}\text { The Marlborough } \\
\text { Express }\end{array}$ \\
\hline $16 / 11 / 2016$ & 3 & Wed & 23:09 & SH63, SH6, SH65 and SH7 is recommended SH1 detour. & NZ Transport Agency \\
\hline $16 / 11 / 2016$ & 3 & Wed & 23:59 & $\begin{array}{l}165 \text { people evacuated from Kaikōura via NZDF } \\
\text { helicopters. }\end{array}$ & Canterbury CDEM \\
\hline
\end{tabular}

\section{DAY 4: Thursday 17th November 2016}

\begin{tabular}{|l|l|l|l|l|l|}
\hline $17 / 11 / 2016$ & 4 & Thurs & & SH7A Open & NZ Transport Agency \\
\hline $17 / 11 / 2016$ & 4 & Thurs & $1: 00$ & $\begin{array}{l}\text { HMNZS Canterbury arrived at Lyttleton. Evacuated 449 } \\
\text { people from Kaikōura. }\end{array}$ & Canterbury CDEM \\
\hline $17 / 11 / 2016$ & 4 & Thurs & $8: 00$ & $\begin{array}{l}\text { Temporary Restricted Area established around Kaikōura } \\
\text { to facilitate safe aircraft operations. Expires 22/11/16 } \\
17: 00 .\end{array}$ & Canterbury CDEM \\
\hline $17 / 11 / 2016$ & 4 & Thurs & $10: 16$ & $\begin{array}{l}\text { Controlled access for residents and emergency services } \\
\text { between Cheviot and Goose Bay (SH1) }\end{array}$ & NZ Transport Agency \\
\hline $17 / 11 / 2016$ & 4 & Thurs & $12: 10$ & $\begin{array}{l}\text { SH1 now open fully between Picton and just south of } \\
\text { Ward. Speed restrictions and many one lane sections } \\
\text { along route. A checkpoint is installed at the end of this } \\
\text { stretch, where the road remains closed. }\end{array}$ & $\begin{array}{l}\text { Marlborough CDEM, } \\
\text { NZ Transport Agency }\end{array}$ \\
\hline $17 / 11 / 2016$ & 4 & Thurs & $16: 30$ & $\begin{array}{l}\text { Bluebridge resume foot passenger travel, Interislander } \\
\text { cannot take foot passengers from Picton to Wellington, } \\
\text { but can take foot passengers from Wellington to Picton. }\end{array}$ & Marlborough CDEM \\
DAY 5: Friday 18th November 2016 & $\begin{array}{l}\text { HMNZS Te Kaha, HMNZS Endeavour, USS Sampson, } \\
\text { HMAS Darwin and HMCS Vancouver call at Wellington } \\
\text { harbour, before leaving for Kaikōura. }\end{array}$ & CentrePort \\
\hline $18 / 11 / 2016$ & 5 & Fri & & $\begin{array}{l}\text { HMNZS Canterbury and international fleet arrives at } \\
\text { Kaikōura, with supplies including 1000+ portable toilets. }\end{array}$ & Canterbury CDEM \\
\hline $18 / 11 / 2016$ & 5 & Fri & $6: 00$ & &
\end{tabular}




\begin{tabular}{|l|l|l|l|l|l|}
$18 / 11 / 2016$ & 5 & Fri & $\begin{array}{l}\text { Wellington Port reopens for cruise ships following } \\
\text { inspections. }\end{array}$ & CentrePort \\
\hline $18 / 11 / 2016$ & 5 & Fri & & $\begin{array}{l}\text { Freight demand on New Zealand's busiest domestic sea } \\
\text { route, Auckland to Christchurch, has doubled following } \\
\text { the massive Kaikōura Earthquake on Monday. }\end{array}$ & KiwiRail \\
\hline $18 / 11 / 16$ & 5 & Fri & $\begin{array}{l}\text { Two out of three Interislander ferries (the Kaiarahi and } \\
\text { Kaitaki) begin carrying foot traffic passengers from } \\
\text { Picton to Wellington. }\end{array}$ & KiwiRail \\
\hline
\end{tabular}

\section{DAY 6: Saturday 19th November 2016}

\begin{tabular}{|c|c|c|c|c|c|}
\hline $19 / 11 / 2016$ & 6 & Sat & $18: 00$ & $\begin{array}{l}\text { HMNZS Canterbury departs Kaikōura for Lyttleton. } \\
\text { Remainder of fleet depart for Wellington. }\end{array}$ & Canterbury CDEM \\
\hline \multicolumn{6}{|c|}{ DAY 7: Sunday 20th November 2016} \\
\hline 20/11/2016 & 7 & Sun & $18: 00$ & $\begin{array}{l}\text { HMNZS Canterbury arrived at Lyttonton. Evacuated } 186 \\
\text { people. }\end{array}$ & Canterbury CDEM \\
\hline \multicolumn{6}{|c|}{ WEEK 2: Monday 21st to Sunday 27th November 2016} \\
\hline $21 / 11 / 2016$ & 8 & Mon & 18:00 & HMNZS Canterbury stood down. & Canterbury CDEM \\
\hline $20 / 11 / 2016$ & 8 & Mon & 18:00 & $\begin{array}{l}\text { SoundsAir launches temporary services, flying daily } \\
\text { between Kaikōura and Christchurch and Blenheim (10- } \\
\text { person flights). On the first flights SoundsAir deliver two } \\
\text { tonnes of mail for New Zealand Post (Christchurch to } \\
\text { Kaikōura), and will make deliveries until the road has } \\
\text { reopened. }\end{array}$ & $\begin{array}{l}\text { Canterbury CDEM, } \\
\text { Marlborough CDEM }\end{array}$ \\
\hline $22 / 11 / 2016$ & 9 & Tue & & $\begin{array}{l}\text { A limited container service begins from Wellington Port } \\
\text { following implementation of on-ship cranes and mobile } \\
\text { cranes on the wharf. The port's container cranes are } \\
\text { currently non-operational and there is liquefaction and } \\
\text { substantial differentiated settlement across the container } \\
\text { operations area. }\end{array}$ & CentrePort \\
\hline $22 / 11 / 2016$ & 9 & Tue & $18: 13$ & M5.7 earthquake near Scargill. & Canterbury CDEM \\
\hline $25 / 11 / 2016$ & 12 & Fri & $15: 00$ & $\begin{array}{l}\text { First Route } 70 \text { convoy of } 81 \text { vehicles from Kaikōura to } \\
\text { Waiau (planned). }\end{array}$ & Canterbury CDEM \\
\hline 25/11/2016 & 12 & Fri & & $\begin{array}{l}\text { Wellington Port receives HMNZS Otago to resupply } \\
\text { following earthquake recovery work in Kaikōura. }\end{array}$ & CentrePort \\
\hline $26 / 11 / 2016$ & 13 & Sat & & $\begin{array}{l}\text { Stock trucks pass through Route } 70 \text { on animal welfare } \\
\text { grounds. Does some damage to the road. }\end{array}$ & Canterbury CDEM \\
\hline
\end{tabular}

WEEKS 3+: Monday 28th November to Friday 9th December 2016

\begin{tabular}{|c|c|c|c|c|c|}
\hline $28 / 11 / 2016$ & 15 & Mon & & $\begin{array}{l}\text { KiwiRail enters the Coastal Shipping market with a new } \\
\text { NZ Connect service, from Auckland's Wiri Inland Port } \\
\text { and KiwiRail's Southdown Freight Hub to Lyttleton's } \\
\text { Midland Port or KiwiRail's Christchurch terminal via } \\
\text { ANL shipping services, in a partnership between } \\
\text { KiwiRail, Ports of Auckland, Lyttleton Port and ANL } \\
\text { Shipping. }\end{array}$ & KiwiRail \\
\hline 28/11/2016 & 15 & Mon & 19:00 & $\begin{array}{l}\text { Civil Aviation Authority restricted airspace over } \\
\text { Kaikōura expires. }\end{array}$ & Canterbury CDEM \\
\hline $29 / 11 / 2016$ & 16 & Tue & & $\begin{array}{l}\text { KiwiRail's rail-enabled Interislander ferry, Aratere, } \\
\text { resumes sailing for freight customers and foot passengers } \\
\text { after the link span at Wellington's ferry terminal, used to } \\
\text { load and discharge vehicles, was repaired. Rail link-span } \\
\text { still under repair so no rail wagons able to be loaded into } \\
\text { Aratere. }\end{array}$ & KiwiRail \\
\hline $29 / 11 / 2016$ & 16 & Tue & 7:00 & $\begin{array}{l}\text { NZ Transport Agency now managing and operating } \\
\text { Route } 70 \text {. Process in place from managing public access } \\
\text { to Route } 70 .\end{array}$ & Canterbury CDEM \\
\hline $4 / 12 / 2016$ & 21 & Sun & $12: 00$ & M5.5 earthquake near Seddon. & Canterbury CDEM \\
\hline $6 / 12 / 2016$ & 22 & Mon & & $\begin{array}{l}\text { SoundsAir adds additional flights between Christchurch } \\
\text { and Blenheim for the Christmas and New Year period. }\end{array}$ & Press \\
\hline $6 / 12 / 2016$ & 23 & Tue & & $\begin{array}{l}\text { The Wellington rail link-span is repaired, allowing rail } \\
\text { wagons to be loaded on to the rail-enabled Aratere } \\
\text { Interislander ferry, and so resume full service. }\end{array}$ & KiwiRail \\
\hline $6 / 12 / 2016$ & 23 & Tue & & Waiau to Kaikōura controlled access (Route 70). & NZ Transport Agency \\
\hline $6 / 12 / 2016$ & 23 & Tue & & $\begin{array}{l}\text { Controlled access for residents and emergency services } \\
\text { from Ward to Clarence (SH1). }\end{array}$ & NZ Transport Agency \\
\hline $12 / 12 / 2016$ & 29 & Mon & 18:00 & Picton to Clarence (SH1) reopens. & NZ Transport Agency \\
\hline $17 / 12 / 2016$ & 34 & Sat & $16: 00$ & $\begin{array}{l}\text { NZ TRANSPORT AGENCY advises delays along } \\
\text { advised SH1 detour (SH63, SH6, SH65, SH7) due to } \\
\text { multiple roadwork sites. }\end{array}$ & NZ Transport Agency \\
\hline $21 / 12 / 2016$ & 38 & Wed & & Waiau to Kaikōura open (Route 70). & NZ Transport Agency \\
\hline
\end{tabular}




\begin{tabular}{|c|c|c|c|c|c|}
\hline 21/12/2016 & 38 & Wed & $14: 26$ & Cheviot to Goose Bay (SH1) open. & NZ Transport Agency \\
\hline $21 / 12 / 2016$ & 38 & Wed & $14: 26$ & $\begin{array}{l}\text { Goose Bay to Peketa (SH1, via Kaikōura) open 6am - } \\
\text { 8pm (SH1). }\end{array}$ & NZ Transport Agency \\
\hline $21 / 12 / 2016$ & 38 & Wed & & $\begin{array}{l}\text { Government announces the North Canterbury Transport } \\
\text { Infrastructure Rebuild (NCTIR) alliance, between NZ } \\
\text { Transport Agency, KiwiRail, Fulton Hogan, Downer, } \\
\text { Higgins and HEB Construction, led by Duncan Gibb, } \\
\text { former lead of the Stronger Christchurch Infrastructure } \\
\text { Rebuild Team (SCIRT). NCTIR is responsible for } \\
\text { managing and operating, as well as all recovery, rebuild } \\
\text { and resilience works, on SH1 and Route } 70 .\end{array}$ & Government \\
\hline $21 / 12 / 2016$ & 38 & Wed & & $\begin{array}{l}\text { Crane arrives to remove containers off train trapped } \\
\text { outside Kaikōura, to be delivered by road. }\end{array}$ & Press \\
\hline $22 / 12 / 2016$ & 39 & Thurs & & $\begin{array}{l}\text { Christchurch to Picton route (SH7, SH65, SH6, SH63) } \\
\text { speed limit reduced from } 100 \mathrm{~km} / \mathrm{h} \text { to } 80 \mathrm{~km} / \mathrm{h} \text {. Wairau } \\
\text { River township speed limit reduced to } 60 \mathrm{~km} / \mathrm{h} \text {. }\end{array}$ & Press \\
\hline 29/12/2016 & 46 & Thurs & $7: 52$ & $\begin{array}{l}\text { Hundalee to Kaikōura (SH1) closed due to weather } \\
\text { conditions causing an increased risk of rockfall. }\end{array}$ & NZ Transport Agency \\
\hline 29/12/2016 & 46 & Thurs & $9: 20$ & Hundalee to Kaikōura (SH1) reopened (6am - 8pm). & NZ Transport Agency \\
\hline 4/01/2017 & 52 & Wed & $14: 20$ & $\begin{array}{l}\text { Peketa to Goose Bay (SH1) closed due to weather } \\
\text { conditions causing an increased risk of rockfall. }\end{array}$ & NZ Transport Agency \\
\hline $4 / 01 / 2017$ & 52 & Wed & 17:00 & Peketa to Goose Bay (SH1) reopened (6am - 8pm). & NZ Transport Agency \\
\hline $9 / 01 / 2017$ & 57 & Mon & $5: 35$ & Peketa to Hunalee (SH1) closed due to a slip. & NZ Transport Agency \\
\hline $9 / 01 / 2017$ & 57 & Mon & 6:00 & $\begin{array}{l}\text { Stop/go required in various locations along SH7 for road } \\
\text { pavement repairs. Expected to last until 20/1/17. }\end{array}$ & NZ Transport Agency \\
\hline $11 / 01 / 2017$ & 59 & Wed & $9: 52$ & Peketa to Hunalee (SH1) reopened (6am - 8pm). & NZ Transport Agency \\
\hline $16 / 01 / 2017$ & 64 & Mon & & $\begin{array}{l}\text { The first freight train to leave the Blenheim Freight Hub } \\
\text { heading south successfully completes its journey to Lake } \\
\text { Grassmere, opening the way for commercial goods to run } \\
\text { again on this section of the South Island's Main North } \\
\text { Line. }\end{array}$ & KiwiRail \\
\hline
\end{tabular}

